\title{
Oceanography and Marine Biology
}

\section{An Annual Review}

\section{Volume 55}

S.J. Hawkins, A.J. Evans, A.C. Dale,

L.B. Firth, D.J. Hughes, and I.P. Smith

First Published 2017

ISBN 978-1-138-19786-2 (hbk)

ISBN 978-1-351-98759-2 (ebk)

\section{Chapter 3}

\section{Ecological Dominance along Rocky Shores, with a Focus on Intertidal Ascidians}

Marc Rius, Peter R. Teske, Patricio H. Manríquez, Rocío Suárez-Jiménez, Christopher D. McQuaid, and Juan Carlos Castilla

(CC BY-NC-ND 4.0)
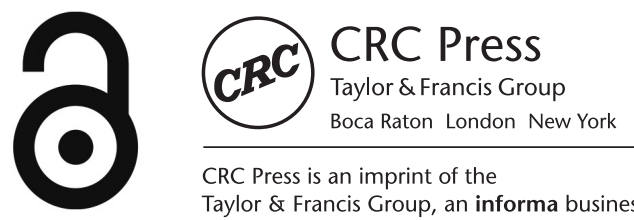

CRC Press is an imprint of the 


\title{
ECOLOGICAL DOMINANCE ALONG ROCKY SHORES, WITH A FOCUS ON INTERTIDAL ASCIDIANS
}

\author{
MARC RIUS ${ }^{1,2 *}$, PETER R. TESKE ${ }^{2}$, PATRICIO H. MANRÍQUEZ ${ }^{3}$, \\ ROCÍO SUÁREZ-JIMÉNEZ ${ }^{4}$, CHRISTOPHER D. MCQUAID ${ }^{5} \&$ JUAN CARLOS CASTILLA ${ }^{6}$
}

${ }^{1}$ Ocean and Earth Science, University of Southampton, National Oceanography Centre, European Way, Southampton, SO14 3ZH, United Kingdom

${ }^{2}$ Centre for Ecological Genomics and Wildlife Conservation, Department of Zoology, University of Johannesburg, Auckland Park, 2006, South Africa

${ }^{3}$ Laboratorio de Ecología y Conducta de la Ontogenia Temprana (LECOT),

Centro de Estudios Avanzados en Zonas Áridas (CEAZA),

Coquimbo, Avenida Ossandón 877, Coquimbo, Chile

${ }^{4}$ Department of Botany, University of Otago, Dunedin 9054, New Zealand

${ }^{5}$ Coastal Research Group, Department of Zoology and Entomology,

Rhodes University, Grahamstown, South Africa

${ }^{6}$ Centro de Conservación Marina, Estación Costera de Investigaciones Marinas (ECIM), Núcleo de Conservación Marina. Iniciativa Científica Milenio. Facultad de Ciencias Biológicas, Pontificia Universidad Católica de Chile, Santiago, Chile

*Corresponding author: Marc Rius

e-mail: M.Rius@soton.ac.uk

The role of dominant species is of central importance in ecology. Such species play a key role in ecosystem structure, stability and function, regulating resource allocation across trophic levels and overall ecosystem productivity. Although ecological interactions between dominant and subordinate species are often considered to influence the latter negatively, the presence of dominant species can also be beneficial. These species commonly act as ecosystem engineers and enhance biodiversity by creating habitat for other species. Along rocky coastlines, dominant species are often sessile suspension-feeding organisms that can monopolize all available substrata. This is particularly noticeable in intertidal and shallow subtidal habitats where the number of species that achieve ecological dominance is limited. Here, we review the ecological and evolutionary mechanisms that facilitate dominance along rocky coastlines. We then focus on a prominent example, the members of the Pyura stolonifera species complex (Tunicata), which are an emerging model system for studying ecological dominance. These ascidians achieve the highest biomass levels ever reported in rocky intertidal habitats and, when invasive, can fundamentally transform entire ecosystems. Finally, we discuss conservation implications and conclude with directions for future research.

\section{Introduction}

Ecological dominance can be defined as "the exertion of a major controlling influence of one or more species upon all other species by virtue of their number, size, productivity or related activities" (United Nations 1997). Interest in ecological dominance extends across a wide range of fields including, for example, paleontology (Clapham et al. 2006) and anthropology (Flinn et al. 2005). 
In ecology, dominance describes the opposite of ecosystem evenness (Hillebrand et al. 2008) and dominant species are generally the most abundant components of natural communities as a result of their competitive superiority. These species have the ability to structure communities in terms of species composition, diversity, biomass, spatial arrangement and occupancy. Additionally, dominant species often function as ecosystem engineers or bioengineer species (Jones et al. 1994, 1997, Nilsson \& Wardle 2005) as they provide habitat for, and regulate the distribution and abundance of other species. Ecological dominance could be construed as including keystone predators or habitatforming seaweeds, but within the context of this chapter we limit it to spatial dominance by sessile or sedentary animals. The persistence of dominant species may depend on certain levels of environmental stochasticity (e.g. disturbance), which maintain stable levels of species diversity and hierarchy (Connell 1978, but see Fox 2013). Consequently, dominant species and disturbance may collectively determine ecosystem stability and levels of functional diversity (Loreau et al. 2001, Smith \& Knapp 2003).

In marine benthic ecosystems, dominant species are often sessile suspension-feeders. These organisms are able to gather and incorporate allochthonous pelagic energy into benthic communities with remarkable efficiency (Gili \& Coma 1998) and monopolize food and spatial resources (Sarà 1986). This is especially noticeable in rocky intertidal and shallow subtidal ecosystems where dominance is often achieved by one or a few suspension-feeding species (e.g. Dayton 1971, Paine 1971, Sousa 1979, Paine et al. 1985, Underwood et al. 1991, Castilla et al. 2000). Dominant suspension-feeders are ecosystem engineer species (Wright \& Jones 2006) and are present in most marine ecosystems around the world (Jones et al. 1994, Crooks 2002, Gutiérrez et al. 2003).

Here, we review the literature to unravel the ecological and evolutionary mechanisms that facilitate dominance. We then focus on a specific group of dominant marine invertebrate species that are of considerable ecological importance in rocky shore communities of the southern hemisphere, the members of the Pyura stolonifera species complex. We conclude with the role of ecological dominance in conservation efforts and outline future directions for research on dominant species.

\section{The theory behind ecological dominance}

Ecological dominance is strongly linked to competitive ability (e.g. Dayton 1975, Steneck et al. 1991, Baird \& Hughes 2000), which is often seen as having negative effects on species richness as competing species work towards eliminating one another. In order to understand how ecological dominance can influence overall community structure, it is important to recognize that competition can take various forms. Theoretically, competition only occurs if specific resources are in limited supply and, in the case of competition for food or space, it can take the form of either exploitation or interference competition (Schoener 1983, Yodzis 1989). Competition for renewable resources such as food often exclusively involves interference, whereas competition for space has two components that operate across different spatial scales and interact with one another: actual competition for space, which operates at small scales through interference, and exploitation competition (Steinwascher 1978) through dispersal, which takes place at larger scales. Dispersal is required to find and to monopolize available space.

In the marine realm, organisms exhibit markedly different scales of propagule dispersal (Kinlan \& Gaines 2003), and this has important consequences for the likelihood of coexistence of competing (and potentially dominant) species (Berkley et al. 2010, Aiken \& Navarrete 2014). When dispersal is minimal, two species can theoretically coexist, as patches of habitat often operate independently of one another (Leibold et al. 2004, Tilman 1994). If dispersal scales are very large, however, the distinction among patches of habitat is lost and coexistence is less likely. Therefore, it is important to measure and define scales carefully when describing the effects of dispersal and 
to recognize that ecological processes are affected by dispersal type (Kinlan et al. 2005, Aiken \& Navarrete 2014). Nevertheless, there are clearly different implications for space occupiers that are assumed to have the potential to disperse over scales of hundreds of kilometres, such as mussels or barnacles (Tapia \& Pineda 2007, Teske et al. 2016) as opposed to those with abbreviated larval development, such as ascidians (Millar 1971, Clarke et al. 1999). Scales of dispersal also have implications for the type of guild responsible for dominating space. Where species are capable of outcompeting others through functional dominance, as is often the case for intertidal communities (e.g. Dayton 1975, Lubchenco \& Menge 1978), the guild is composed of dominant space occupiers. In this case, weakening of dominance results in an increase in the number of species that can coexist so that non-selective mortality, common in cases of mass mortality due to wave or heat stress (e.g. Tsuchiya 1983, Erlandsson et al. 2006, Garrabou et al. 2009), has a positive effect on species richness. In contrast, in ecosystems without clear competitive dominance, the system is shaped by dispersal and colonization events and is considered to be founder-controlled. Such systems include coral reef fish communities (e.g. Sale 1977, 1979, Almany et al. 2007) and in this case, mortality will decrease richness (Paine 1966, Sousa 1979, Yodzis 1989).

There is a vast body of both theoretical and empirical literature on resource-mediated interactions in communities dominated by superior competitors, including the implications for the control of species richness, the persistence of subordinate species (Dayton 1975), shifting competitive dominance (Paine 1969, Lubchenco 1978) and ecological consequences of body size (Brown \& Maurer 1986). Of course, dominant species interact with other drivers of community structure, including keystone species (Paine 1969, Paine \& Suchanek 1983, Menge et al. 1994, Castilla 1999), recruitment limitation (Connolly \& Roughgarden 1999) and disturbance (Lubchenco \& Menge 1978, Sousa 1979). Importantly, and partly through their effects on other species, dominant species can regulate ecosystem function, trophic complexity and community stability (Paine 1969, Smith \& Knapp 2003), which leads to community-level impacts (Harley 2006). More recently, it has been recognized that species that occupy primary space interact not only with other space-occupiers, but also have a key role in enhancing species richness through facilitation. The inclusion of facilitation in ecological models can completely alter predictions of the effects of environmental stress, disturbance or predation on species richness and the probability of success of biological invasions (Bruno et al. 2003). This builds on the recognition of the importance of within-species group effects for space-occupiers (Bertness \& Leonard 1997) and their role as ecological engineers (Jones et al. 1994). Dominant species can provide habitat for associated species, offer protection from predation (Stachowicz \& Hay 1999, Crain \& Bertness 2006), mitigate environmental stress (Rius \& McQuaid 2006, 2009) and enhance recruitment success of conspecifics (Erlandsson \& McQuaid 2004) as well as other species. For example, successful settlement of mussel recruits can be enhanced by the presence of macroalgae (Bayne 1964, McQuaid \& Lindsay 2005).

Resource availability is a critical mechanism modulating ecosystems. It determines community structure, ecological interactions and phenotypic traits (Coley et al. 1985), and it shapes levels of energy transfer across trophic levels that are required to maintain niche differentiation and functional diversity. Along rocky coastlines, the primary limiting factor for benthic organisms is space, which in the intertidal zone can be dominated by both sessile animals and algae. However, the balance between faunal and algal dominance is often mediated by wave action (McQuaid \& Branch 1984). At the subtidal fringe, space is mostly dominated by suspension-feeders, with ascidians dominating many temperate coastlines, especially in the Southern Hemisphere (see below).

The monopolization of a specific resource by a single species is generally ascribed to certain attributes (Paine \& Suchanek 1983, Guiñez \& Castilla 2001). Accordingly, it is expected that competitive dominance will positively correlate with degree of gregariousness and the species' ability to occupy space (Figure 1). Among the species traits that enhance ecological dominance (Figure 2), gregariousness and a sessile or sedentary life strategy are tightly linked (i.e. it is difficult to have one trait without the other), and collectively lead to a specific ecological trade-off. A gregarious 
Figure 1 Drivers and consequences of ecological dominance in benthic animals. Nested ellipsoids represent isobars of likelihood of becoming a dominant species.
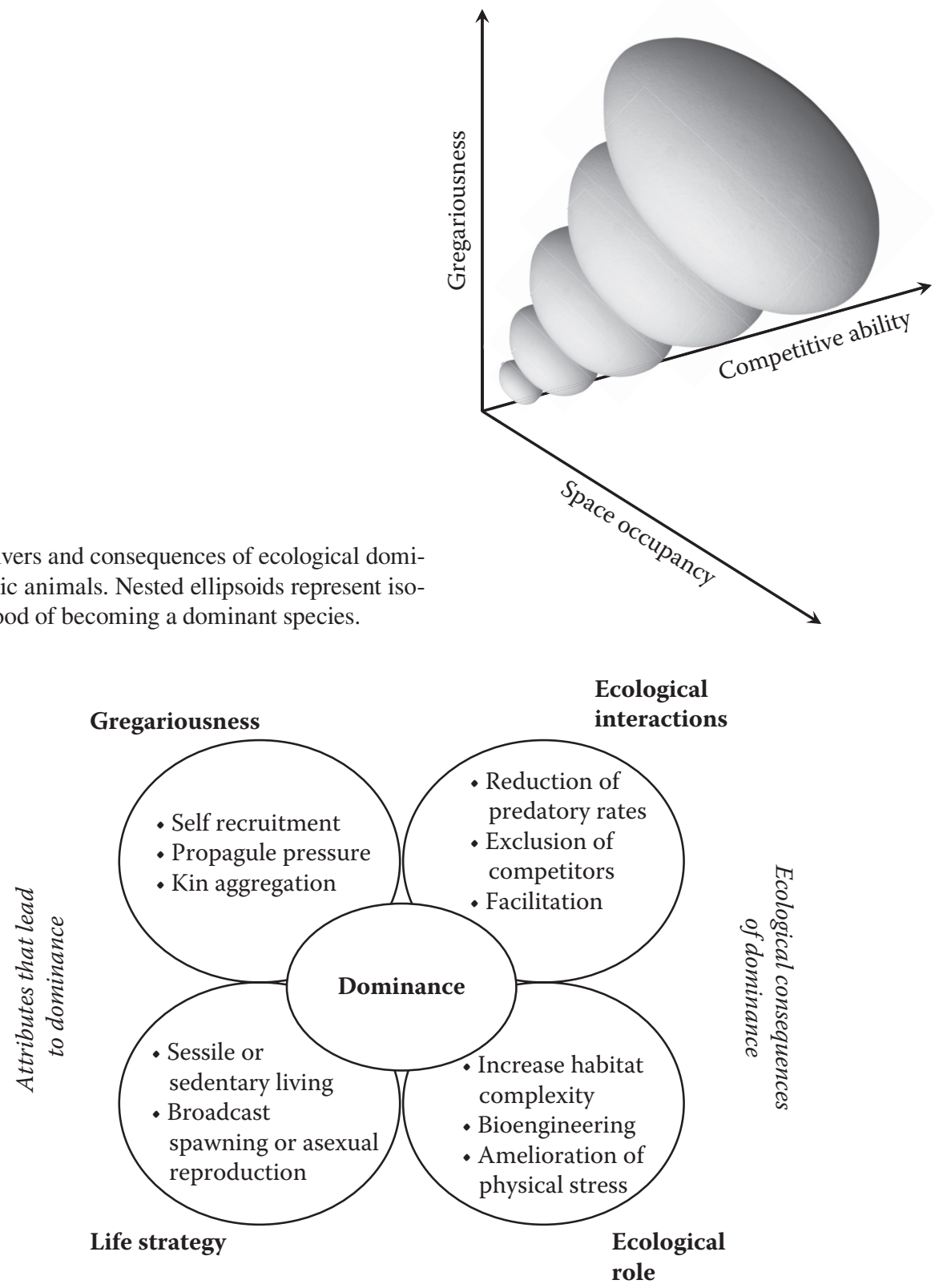

Figure 2 Drivers and consequences of ecological dominance in benthic animals. Shown are main attributes leading to dominance, together with consequences of the presence of dominant species.

species can act as a bioengineer and occupy space while the ability of its predators or competitors to fulfil their roles diminishes. A key aspect for dominance is to maximize the extent and duration of resource monopolization. Species such as ephemeral algae are rarely considered dominant species as they are short-lived and space occupancy is only transient.

The monopolization of resources, particularly space, can be mitigated by compensatory mortality, with dominant species suffering higher rates of mortality through disturbance (e.g. Connell 
1978, Paine 1979, Sousa 1979, Erlandsson et al. 2006) or predation (Paine 1976, Symondson et al. 2002). The effects of predation can depend on timing in terms of ecological succession (Vieira et al. 2012) and recruitment rates high enough to swamp predators can ultimately allow monopolization (Navarrete \& Berlow 2006). Thus, disturbance and predation generally tend to free resources and ameliorate the subordination of inferior species. This reduces interference competition and allows species to exploit spatial and temporal variability in resources, minimizing dominance by a particular species.

\section{Evolutionary implications of ecological dominance}

The formation of aggregations by propagules that disperse freely in a particular environment requires certain behavioural abilities. For example, behaviour-mediated recruitment has been reported in many taxa (Toonen \& Pawlik 1994) and is often a response to the presence of conspecific adults (Toonen \& Pawlik 1996, Alvarado et al. 2001). However, other external stimuli such as light, biofilm, substratum orientation or flow conditions may be more relevant (Pawlik et al. 1991, Keough \& Raimondi 1995, Wieczorek \& Todd 1997, Rius et al. 2010a). In addition, evolutionary mechanisms such as Allee effects may be critical for understanding ecological dominance. Allee effects normally appear when there is a decline in population size or density that leads to a loss of overall fitness (Courchamp et al. 1999, Berec et al. 2007). These effects can operate through increased difficulty in finding mates (e.g. Kuussaari et al. 1998) or susceptibility to predators (e.g. Bertness \& Grosholz 1985). Additionally, because most broadcast-spawning benthic suspension-feeders are sessile (e.g. ascidians) or near-sessile (e.g. mussels), populations often exhibit Allee effects because the likelihood of gamete encounters resulting in fertilization is significantly lower when adults are present at low densities (Levitan 1991, Babcock \& Keesing 1999).

For many organisms, ecological dominance is largely a consequence of the behaviour of their dispersive larvae, which enables the formation of long-lasting aggregations. Aggregated settlement can be facilitated by conspecific cues following successful colonization by a founder (Toonen \& Pawlik 1994). Indeed, a possible evolutionary consequence of Allee effects is conspecific attraction. Although the idea of linking Allee effects, recruitment and conspecific attraction was developed in the context of vertebrates, especially colonial- and non-colonial-nesting birds (Reed \& Dobson 1993), the insights gained are applicable to species with external fertilization. Stephens \& Sutherland (1999) regard conspecific attraction as a "direct product" of Allee effects and Donahue (2006) suggests that conspecific cues and Allee effects jointly lead to conspecific attraction. Another aspect that may be relevant is kin aggregation (Grosberg \& Quinn 1986, Veliz et al. 2006), although the reverse situation (kin avoidance) has also been reported (Johnson \& Woollacott 2010) and thus requires further investigation.

Propagule attraction to conspecifics can be facilitated by increased habitat complexity. For example, studies have shown increased settlement rates in structurally-complex mussel beds (Alvarado \& Castilla 1996, Alvarado 2004), though there is responsiveness to conspecifics in the absence of structural complexity that can change with settler age (von der Meden et al. 2010). Attraction to adult conspecifics can have negative consequences in the case of suspension-feeders that feed indiscriminately, such as adult mussels which are able to consume $>70 \%$ of potential settlers, including conspecifics, through larviphagy (Lehane \& Davenport 2004, Porri et al. 2008, Troost et al. 2008). In addition, self-recruitment (i.e. recruitment of progeny to the parental population or patch) may increase levels of inbreeding (potentially promoting low levels of genetic diversity), which is known to negatively affect population persistence (Keller \& Waller 2002). Despite the potential negative effects, settling close to parents seems to have remarkable fitness benefits in some taxa. The positive aspects of attraction of settling larvae to adults are chiefly due to the enhancement of fertilization success via adult aggregation. In the case of broadcast spawners, fertilization success is often correlated with the degree of aggregation (Levitan et al. 1992, Downing et al. 1993). In addition, aggregations can have evolutionary benefits by providing group defence against predators. For example, mussels use byssal 
threads to trap predatory whelks (Day et al. 1991, Farrell \& Crowe 2007) and to mutually protect conspecifics from wave action (van de Koppel et al. 2005). The latter can also involve facilitative interspecific effects between ecologically homologous species (e.g. Rius \& McQuaid 2009).

\section{Ecological dominance on rocky shores}

Intertidal habitats have long been model systems for the study of ecological dynamics and principles (Paine 1966, 1969, Stephenson \& Stephenson 1972, Lubchenco \& Gaines 1981, Hawkins \& Hartnoll 1983b, Branch 1984, Castilla \& Durán 1985, Menge \& Sutherland 1987, Menge et al. 1994, Underwood 2000, Navarrete \& Castilla 2003). They can support sessile consumers because food can be transported through the aquatic medium itself, and in many systems, suspension-feeders maintain extremely dense populations (Monteiro et al. 2002, Castilla et al. 2004b). These species dominate overall biomass (e.g. McQuaid \& Branch 1984, Castilla et al. 2000) and energy flow (Newell et al. 1982) because of their high rates of secondary production (Baird et al. 2004). Dominant rocky shore species filter large volumes of water and suspended particles (mainly originating from primary production), creating a habitat for diverse associated biota. This gives such species a number of critical roles in ecosystem functioning. Firstly, they act as primary consumers, linking primary production and secondary consumers (Gili \& Coma 1998), critically contributing to remineralization (Eriksson et al. 2010) and benthic-pelagic coupling. This creates a two-way interaction between the water column and the benthos through both the consumption of suspended particles (McQuaid \& Branch 1985, Loo \& Rosenberg 1989, 1996) and the benthic recruitment of planktonic larvae (Navarrete et al. 2005). Secondly, dominant rocky shore species can act as autogenic ecological engineers (sensu Lawton \& Jones 1995), occupying all available primary space (e.g. Castilla et al. 2004a), and in doing so increasing architectural complexity (Hughes \& Griffiths 1988, Guiñez \& Castilla 1999, 2001), which enhances species richness (Cerda \& Castilla 2001, Cole \& McQuaid 2010). All these characteristics make this group a unique and important component of benthic communities.

Mass mortalities of dominant suspension-feeding species as a result of extreme environmental stress or disease (e.g. Hanekom et al. 1999), can have important implications for the entire rocky shore ecosystem. One direct consequence is the loss of ecological networks and function. For example, drastic reductions of intertidal suspension-feeding species directly modify the intertidal community structure and zonation, impacting on key ecosystem services (Castilla et al. 2014, Manríquez et al. 2016). Another consequence of major disturbance events is the decrease of structural complexity upon which other species depend. This is particularly critical when the spatially-dominant species lack a hard calcareous skeleton, such as ascidians (Cerrano \& Bavestrello 2009). However, in the case of calcareous species such as barnacles, habitat complexity can persist after mortality. Patch fragmentation as a result of disturbance has major effects on dominant suspension-feeding species and associated communities, contributing to a non-random community assembly in intertidal areas.

Ecological dominance along rocky shores is achieved by a small, taxonomically-diverse group of species. Some examples include bivalves, tubeworms, bryozoans and solitary ascidians (Figure 3), all broadcast-spawning organisms with well-studied life histories (Marshall \& Keough 2008, Marshall et al. 2012). These taxa have a wide variety of dissimilar characteristics (Figure 3), indicating that ecological dominance is not due to analogous combinations of traits.

\section{The Pyura stolonifera species complex: A model system for studying ecological dominance}

Members of the Pyura stolonifera species complex (sensu Rius \& Teske 2011, Phylum Chordata, Subphylum Tunicata) (hereafter the P.s.s.c.) are amongst the few intertidal solitary ascidian species that form extensive and dense monospecific aggregations, dominating all available substrata. These 


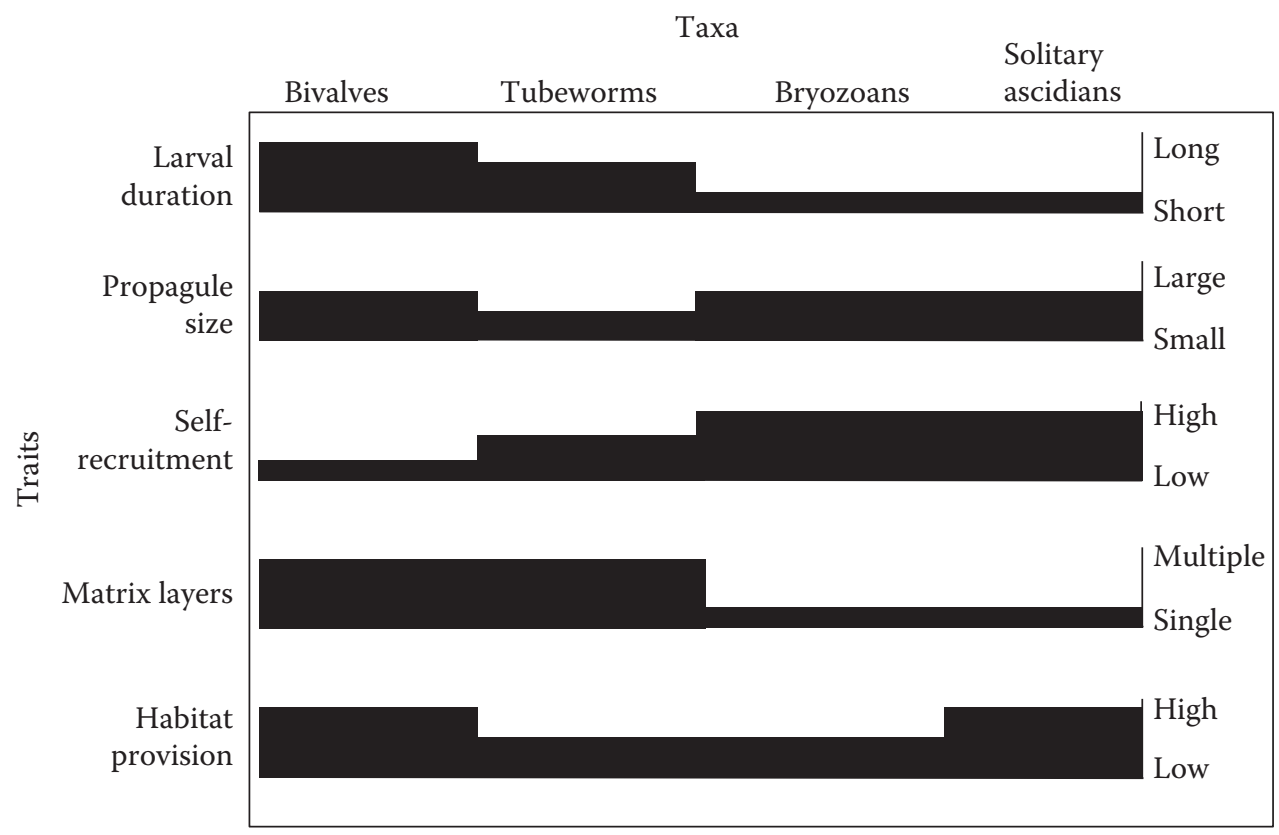

Figure 3 Generalized trait variation of four sessile or sedentary suspension-feeding taxa that are able to dominate rocky shores. The selected traits are all key for understanding ecological dominance and they influence different life-history stages, from early ontogenetic life stages (top) to adulthood (bottom). The right $\mathrm{x}$-axis provides a general idea of rankings and allows overall comparison. Propagule size refers to the size of motile early life-history stages, which in broadcast spawning species is generally correlated with the size of the juvenile and adult stages (Rius et al. 2010b). Self-recruitment refers to recruitment of progeny to the parental population or patch. Matrix layers refer to the ability of dominant species to form multilayer assemblages, which provide secondary habitat for other species.

species are roughly barrel-shaped tunicates that can grow to $>30 \mathrm{~cm}$ in height (Paine \& Suchanek 1983, Fielding et al. 1994, Castilla et al. 2000). They form extensive cemented aggregations or 3-dimensional matrices (Guiñez \& Castilla 2001) in the form of collective packed units, although isolated individuals also occur (Castilla \& Camaño 2001, Monteiro et al. 2002). Members of the P.s.s.c. produce the highest intertidal biomass per unit surface area ever reported in the literature, with dry tissue biomass of $>20 \mathrm{~kg} \mathrm{~m}^{-2}$ and densities of up to 1800 individuals $\mathrm{m}^{-2}$ (Fielding et al. 1994, Castilla et al. 2000). Such biomass is an order of magnitude higher than the maximum values reported for other suspension-feeding species along rocky shores (e.g. McQuaid \& Branch 1985). Ecological theory predicts that the area on either side of the Low Water Springs level is dominated by highly competitive species that are generally free from predators (Hawkins \& Hartnoll 1983). Accordingly, intertidal populations of the members of the P.s.s.c. achieve the highest densities and biomass in this particular area (Castilla et al. 2000). The members of the P.s.s.c. each present unique bioengineer habitat architectures in terms of the number, size and shape of individuals and the arrangements of habitable secondary space. Overall, these ascidians represent good models for the study of ecological dominance in benthic communities (Monteiro et al. 2002, Castilla et al. 2004b, Teske et al. 2011, Manríquez et al. 2016).

Information on the P.s.s.c. has been accumulating over the past 130 years or so, from taxonomic (Heller 1878, Van Name 1945, Millar 1955, 1966, Monniot \& Bitar 1983, Rius \& Teske 2011) and ecological studies (Guiler 1959, Stephenson \& Stephenson 1972, Paine \& Suchanek 1983, Clarke et al. 1999, Castilla et al. 2000, Monteiro et al. 2002, Castilla et al. 2004a, Castilla et al. 2004b, Knott et al. 2004, Rius et al. 2010a) to recent studies of its physiology (Rius et al. 2014a), genetics 
(Castilla et al. 2002, Astorga et al. 2009, Teske et al. 2011, Rius \& Teske 2013), invasion biology (Castilla et al. 2004a, Hayward \& Morley 2009, Teske et al. 2011, Rius \& Teske 2013) and exploitation by humans (Kyle et al. 1997, Castilla et al. 2014, Manríquez et al. 2016). Below, we analyze the biological attributes that have allowed this group to become successful in dominating rocky shores.

\section{Biogeography and evolutionary history of the species complex}

Despite the conspicuous nature of the members of the P.s.s.c. in both intertidal and subtidal environments, the taxonomy of the group has been fiercely contested until very recently (Kott 2006, Rius \& Teske 2011). Many papers referred to all the members of the P.s.s.c. as Pyura stolonifera (e.g. Kott 1985, Marshall et al. 2000) despite taxonomic (Millar 1962, Monniot \& Bitar 1983, Monniot et al. 2001), ecological (Dalby 1997) and genetic (Castilla et al. 2002) evidence pointing to the existence of multiple species. Recent studies employing a combination of morphological and genetic analyses (Rius \& Teske 2011, 2013, Teske et al. 2011) have revealed that Pyura stolonifera (Heller, 1878) as defined by Kott (2006) is a species complex that in fact represents at least five distinct species. The species presently accepted as valid are the African representatives $P$. stolonifera and $P$. herdmani (Drasche, 1884), and the Australian P. praeputialis (Heller, 1878), P. dalbyi (Rius \& Teske, 2011) and $P$. doppelgangera (Rius \& Teske, 2013).

Members of the P.s.s.c. are predominantly found along temperate rocky shores of the Southern Hemisphere. In particular, most species are distributed along southern African (Millar 1955, Monniot \& Monniot 2001) and Australian (Kott 1985) coasts, but one member of the P.s.s.c. (Pyura herdmani) is also present in the Northern Hemisphere (Monniot \& Bitar 1983, Lafargue \& Wahl 1986-1987, Teske et al. 2011). The different species are typically allopatric and some exhibit disjunct distributions, with populations that are separated by large geographic distances (Castilla \& Guiñez 2000, Rius \& Teske 2013), but there are also instances of sympatric distributions in southern Africa and Australia (Figure 4). Reports from South America (Clarke et al. 1999) and New Zealand (Hayward \& Morley 2009) that are corroborated by genetic evidence (Teske et al. 2011), as well as recent sightings in Europe (see further details below), suggest that the species found in these regions originated from elsewhere and were most likely introduced through human activities.

Temperate coastlines characterized by upwelling systems are often preferred habitats for members of the P.s.s.c. (Figure 4). Some species, such as Pyura herdmani in Africa, are widespread and occur across several biogeographic provinces of differing temperature regimes, providing an interesting system to study population connectivity and physiological tolerance across ecoregions. Another interesting case is $P$. dalbyi, which shows a large distribution gap between the southwestern and southeastern coasts of Australia (Figure 4). However, much of the intermediate region is part of the Great Australian Bight, which is highly inaccessible to study, so this species may be more widespread.

The presence of members of the P.s.s.c. on land masses that formed part of the former supercontinent of Gondwanaland (Africa, Australasia and South America) suggests that the present species shared a common ancestor during the Mesozoic. Interestingly, despite treating all as a single species, Kott $(1985,2006)$ favoured a Gondwanan origin for the group, notwithstanding the fact that tens of millions of years are ample time for speciation to occur. While it is now believed that the populations in South America and New Zealand are the product of recent anthropogenic introductions from Australia (see below), phylogenetic work indicates that there is an ancient split between evolutionary lineages comprising the African species (Pyura stolonifera and P. herdmani) on one hand, and two of the Australian ( $P$. praeputialis and $P$. doppelgangera) species on the other (Teske et al. 2011). This split has not yet been dated, and a shared Gondwanan ancestry of these two lineages thus remains a possibility. However, such a scenario would have involved extinctions on all of the remaining Gondwanan land masses (Madagascar, India, South America, New Zealand and 


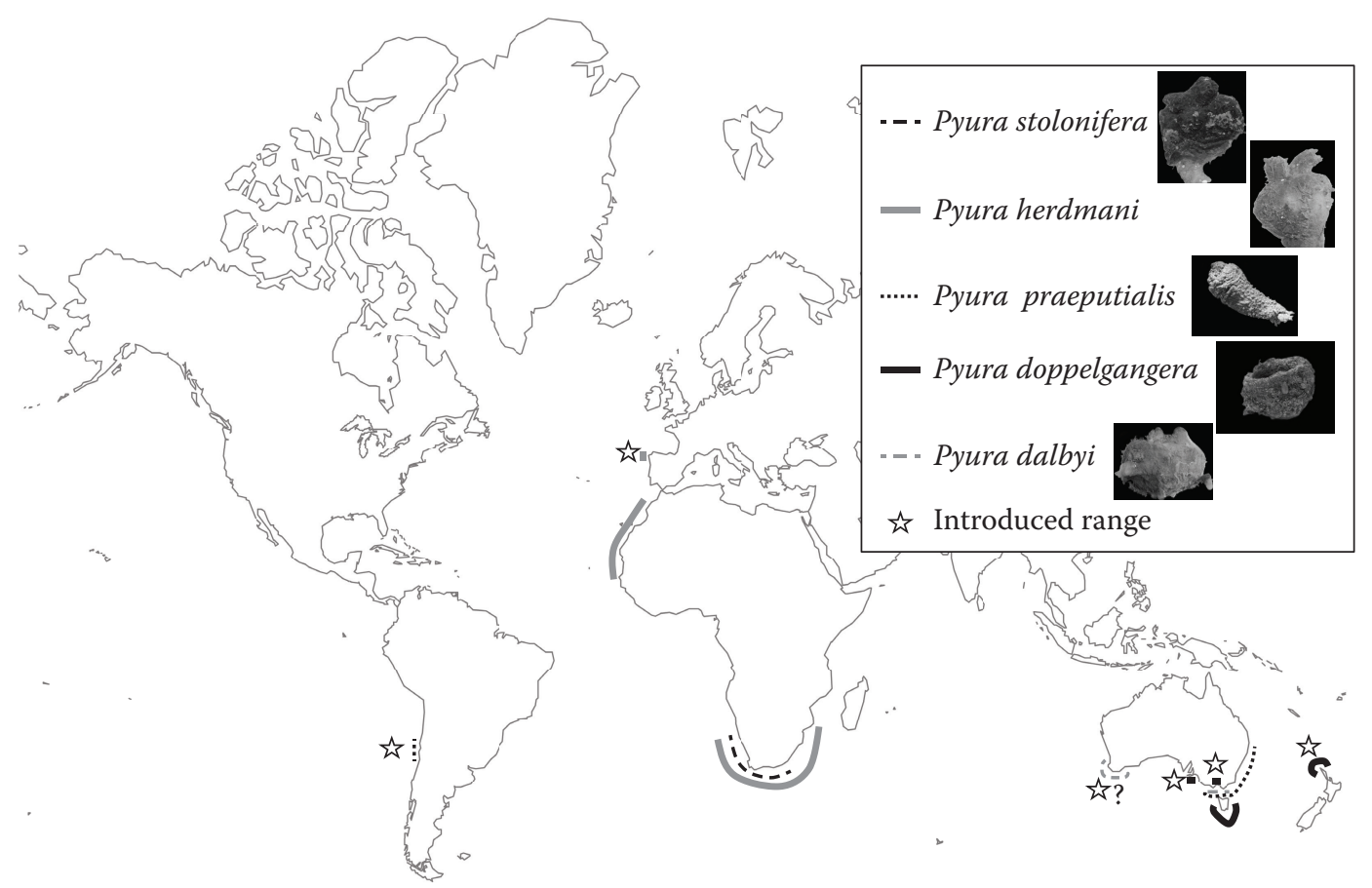

Figure 4 Global distribution of the members of the Pyura stolonifera species complex, with the introduced ranges of the different species indicated.

Antarctica), which is a less parsimonious solution than a single long-distance colonization event (e.g. from Africa to Australia via the West Wind Drift). The gametes and larvae of ascidians are unable to disperse over greater distances because of their very short planktonic propagule durations (Millar 1971, Clarke et al. 1999, Rius et al. 2010b), but it is well known that the adults can travel attached to vessels or other floating objects (Lambert 2007, Locke 2009). There is thus little reason to rule out the possibility that the disjunct distribution of the African and Australian lineages was the result of an ancient long-distance colonization event.

\section{Reproductive cycle, early life-history stages, settlement and fertilization}

The members of the P.s.s.c. have a multiphasic life-cycle (Figure 5) and are broadcast-spawning simultaneous hermaphrodites, releasing male and female gametes mainly during low tides (Marshall 2002, Manríquez \& Castilla 2010). After release, currents disperse the gametes, reducing the likelihood of inbreeding. In addition, members of the P.s.s.c. have blocks to self-fertilization since eggs of Pyura praeputialis fertilized with self-sperm fail to complete development (Manríquez \& Castilla 2010). As a result, fertilization and developmental success rely mainly on allogametes encountering one another, which in turn depends on the concentration of allosperm and the viability of eggs (see Marshall 2002, Manríquez \& Castilla 2010). Fertilization success in P. praeputialis is at its highest with newly-shed sperm and declines as sperm and eggs age (Manríquez \& Castilla 2010). Since allogamete limitation as a result of the rapid dispersion of gametes may occur along exposed rocky shores, some members of the P.s.s.c. have developed strategies to counteract gamete dilution and mitigate the difficulties of fertilization in such environments. Gamete retention close to the parents following spawning has been observed in P. praeputialis both in Australia (Marshall 2002) and Chile (Manríquez \& Castilla 2010) and, although this has not yet been described in other members 


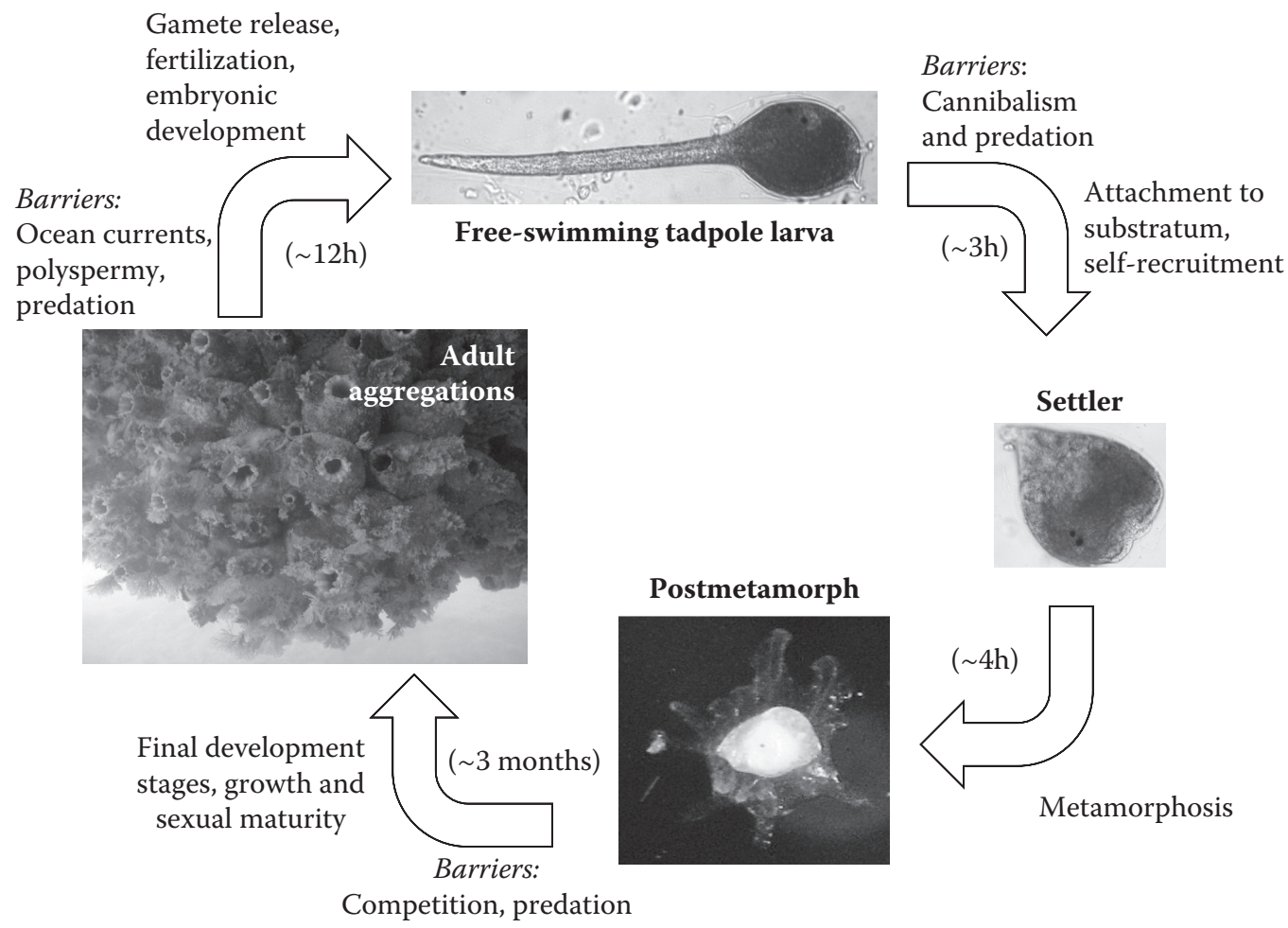

Figure 5 Life cycle of Pyura herdmani depicting different life-history stages and key barriers that may preclude ecological dominance. Early life-history stages were obtained via artificial fertilization in the laboratory (see details in Rius et al. 2010a). All photographs were taken in South Africa.

of this complex, it is highly plausible that it occurs. The gametes of $P$. praeputialis are often shed in a viscous matrix (Marshall 2002, Castilla et al. 2007b, Manríquez \& Castilla 2010) and once they come into contact with seawater a biofoam is formed (Castilla et al. 2007b, Manríquez \& Castilla 2010). Such biofoam also retains a high concentration of developing embryos and larvae of $P$. praeputialis (Castilla et al. 2007b, Manríquez \& Castilla 2010). This suggests that biofoam formation may be an adaptive mechanism that enhances fertilization success and self-recruitment.

After fertilization, embryonic development occurs rapidly (see details in Rius et al. 2010a) and results in tadpole-like larvae that have a very short swimming period (Figure 5). The larvae are lecithotrophic and dependence on limited yolk-reserves limits dispersal range. As a result of the short pelagic duration of gametes, embryos and larvae, settlement will occur in the vicinity of the parental habitat, and colonization of new areas (away from the parental populations) requires the dispersal of adults that have settled on moving objects, such as boats or floating debris (Teske et al. 2015). Since direct observation of pelagic dispersal is challenging, genetic tools are often used to estimate population connectivity (e.g. Teske 2014) and confirm that levels of self-recruitment are high (Teske et al. 2015).

Although experimental trials using Pyura stolonifera and P. herdmani larvae showed that settlement occurs irrespective of the presence of adult tunic extracts (Rius et al. 2010a), the highest recruitment in the field is consistently reported on the tunics of adults or on substrata in the immediate vicinity (Alvarado et al. 2001, Marshall 2002, Monteiro et al. 2002, Castilla et al. 2014, Manríquez et al. 2016). More studies are however needed to confirm if self-recruitment is consistently present in aggregations of these ascidians. Taken together, gamete release synchrony, as well as strategies to retain early life-history stages, facilitate ecological dominance by members of the P.s.s.c. along rocky shores. 


\section{Suspension-feeding and diet}

Species of the P.s.s.c. are, like the great majority of ascidians, ciliary-mucus active sieving suspension-feeders (Bone et al. 2003). Water filtration is extremely efficient, even for particles as small as 2-3 $\mu \mathrm{m}$, with food items including detrital organic matter, diatoms and other phytoplankton, and suspended bacteria (Millar 1971, Monniot et al. 1991, Bak et al. 1998, Tyree 2001, Lambert 2005). Although no evidence of particle selection has yet been reported (Randløv \& Riisgård 1979), studies of the gut of Pyura stolonifera suggest that phytoplankton is a much more important energy source than macroalgal detritus (Seiderer \& Newell 1988). Other potential food items include developing stages and larvae of other invertebrate species, including self- and allogametes. Gut content analysis of adult individuals of $P$. praeputialis shows the presence of annelid, crustacean and mollusc larvae (Table 1). In addition, faecal pellets of $P$. praeputialis collected in the field contained tadpole larvae of $P$. praeputialis, mytilid larvae and newly hatched veliger larvae of the gastropod Concholepas concholepas (Table 2). Regardless of whether or not these items are digested, the available information suggests that members of the P.s.s.c. interact with other species inhabiting the same area by reducing food availability and by directly consuming early life-history stages.

The rates of filtration by ascidians generally depend on body size (Monniot et al. 1991) and seawater temperature (Fiala-Médioni 1978, Petersen \& Riisgård 1992, Ribes et al. 1998). For Pyura stolonifera, filtration rates increase with the size of the branchial sacs (Klumpp 1984) and ciliary bands lining the stigmatal openings (Petersen \& Svane 2002). Large individuals of P. stolonifera can filter up to 18 litres seawater $h^{-1}$ (Klumpp 1984).

Table 1 Stomach content (mean number of individual food items counted \pm SE) of Pyura praeputialis collected at two sampling sites in Antofagasta Bay, Chile

\begin{tabular}{|c|c|c|}
\hline & El Way $(\mathrm{n}=21)$ & Las Conchitas $(\mathrm{n}=20)$ \\
\hline Foraminifera $(\mathrm{i}$, a) & $11.67 \pm 1.67$ & $3.40 \pm 1.02$ \\
\hline Tintinnida $(\mathrm{j}, \mathrm{a})$ & $1.00 \pm 10.29$ & 0 \\
\hline Nematoda (j, a) & $0.10 \pm 0.07)$ & $0.10 \pm 0.10$ \\
\hline Gastropoda $^{(j)}$ & $2.10 \pm 0.48$ & $2.05 \pm 0.84$ \\
\hline Mytilidae $^{(1, j)}$ & $1.38 \pm 0.30$ & $18.25 \pm 10.23$ \\
\hline Annelida ${ }^{(1, j)}$ & $0.10 \pm 0.10$ & 0 \\
\hline Crustacea (unidentified) & $0.29 \pm 0.20$ & $0.40 \pm 0.24$ \\
\hline Nauplii & $1.86 \pm 0.46$ & $0.60 \pm 0.60$ \\
\hline Cyprids & $1.48 \pm 0.35$ & $0.25 \pm 0.16$ \\
\hline \multicolumn{3}{|l|}{ Copepoda } \\
\hline Harpacticoida (j, a) & $0.38 \pm 0.13$ & $0.40 \pm 0.23$ \\
\hline Calanoida $^{(\mathrm{j}, \mathrm{a})}$ & $0.67 \pm 0.17$ & $1.60 \pm 0.60$ \\
\hline Cyclopoida $^{(\mathrm{j}, \text { a) }}$ & $0.33 \pm 0.17$ & $0.15 \pm 0.08$ \\
\hline Bacillariophyceae & $3.33 \pm 0.87$ & $0.55 \pm 0.17$ \\
\hline \multicolumn{3}{|l|}{ Dinoflagellata } \\
\hline Protoperidinium sp. & $0.81 \pm 0.25$ & $0.70 \pm 0.47$ \\
\hline Ceratium sp. & $0.14 \pm 0.10$ & $0.20 \pm 0.20$ \\
\hline Algal detritus & $\mathrm{p}$ & $\mathrm{p}$ \\
\hline Silt & $\mathrm{p}$ & $\mathrm{p}$ \\
\hline Faecal pellets & $\mathrm{p}$ & $\mathrm{p}$ \\
\hline \multicolumn{3}{|c|}{$\begin{array}{l}\text { Sampling was conducted between February and May } 1998 \text { (El Way, } \\
23^{\circ} 45^{\prime} \mathrm{S} ; 70^{\circ} 26^{\prime} \mathrm{W} \text { ) and March and May } 1998 \text { (Las Conchitas, } \\
23^{\circ} 31^{\prime} \mathrm{S} ; 70^{\circ} 32^{\prime} \mathrm{W} \text { ). Key: } \mathrm{p}=\text { present but not quantified, }{ }^{1}=\text { larvae, } \\
\mathrm{j}^{\mathrm{j}}=\text { juveniles, }{ }^{\mathrm{a}}=\text { adults. }\end{array}$} \\
\hline
\end{tabular}


Table 2 Pyura praeputialis consumption of embryos and larvae when biofoam is present and absent

\begin{tabular}{lcc}
\hline & Pools with biofoam $(\mathrm{n}=15)$ & Pools without biofoam $(\mathrm{n}=17)$ \\
\hline Developing embryos $^{\mathrm{a}}$ & $0.83 \pm 0.21$ & 0 \\
Tadpole larvae $^{\mathrm{a}}$ & $0.41 \pm 0.13$ & $0.03 \pm 0.03$ \\
Mytilidae larvae $^{\mathrm{b}}$ & $0.84 \pm 0.22$ & $0.10 \pm 0.06$ \\
Gastropod larvae $^{\mathrm{c}}$ & $0.15 \pm 0.21$ & $0.03 \pm 0.21$ \\
\hline
\end{tabular}

Note: The abundance (mean $\pm \mathrm{SE}$ ) of developing embryos or larvae per unit length of the faecal pellet is indicated. Faecal pellets were collected from the field in May 2004 at El Way (23 $45^{\prime}$ S, $\left.70^{\circ} 26^{\prime} \mathrm{W}\right)$ in Antofagasta Bay, Chile, approximately two hours after a spawning of Pyura praeputialis. They were collected from the vicinity of the exhalant siphon of individuals present in small rocky intertidal pools. Faecal pellets were collected from several pools with $(n=50$ pellets) and without $(n=50$ pellets) surface biofoam.

a Embryonic stages (ca. $200 \mu \mathrm{m}$, total length) and hatched Pyura praeputialis tadpole larvae $(120 \times 1200 \mu \mathrm{m}$; trunk and total length) (see Clarke et al. 1999).

b Prodisoconch and disoconch larvae, presumably Perumytilus purpuratus with sizes ranging from 100-180 $\mu \mathrm{m}$ (see Ramorino \& Campos 1983).

c Newly hatched larvae of Concholepas concholepas of about $250 \mu \mathrm{m}$ in size (see Manríquez et al. 2014).

Laboratory studies of Pyura stolonifera showed 100\% retention efficiency when individuals were offered cells of the alga Dunaliella primolecta of sizes ranging from 4 to $6.35 \mu \mathrm{m}$ (Stuart \& Klumpp 1984). The same was found by Klumpp (1984) when food particles from the field were analyzed. These studies suggest that Pyura stolonifera is a non-selective suspension-feeder and that this may contribute to their competitive superiority over coexisting species, such as bivalves and sponges (Stuart \& Klumpp 1984).

The risk of predation is a major selective pressure driving the evolution of larval settlement strategies in marine invertebrates (Thorson 1950). Young (1988) reported that gregarious species such as Pyura haustor rejected their own eggs and larvae as food, which can be seen as an adaptive strategy to avoid cannibalism. The large inhalant siphon of the members of the P.s.s.c. (diameter up to $1.5 \mathrm{~cm}$ ) does not allow discrimination among suspended particles, and high levels of consumption of conspecific offspring have been reported (see Table 2). In addition, rates of cannibalism of larvae are extremely high when mechanisms of gamete and larval retention (e.g. biofoam) are present (Castilla et al. 2007b, Manríquez \& Castilla 2010). This suggests that in the absence of biofoam the gametes spawned are not present or are considerably diluted, so there is little or no opportunity for cannibalism.

\section{Community structure and ecological interactions}

Members of the P.s.s.c. are fierce competitors for space, outcompeting individuals at intra-specific (Dalby 1995, Guiñez \& Castilla 2001) and inter-specific (Castilla et al. 2004a, Caro et al. 2011, Manríquez et al. 2016) levels. Experimental studies of intertidal aggregations of Pyura praeputialis in Antofagasta Bay, Chile (where this species is invasive), showed that as aggregates reach high population densities, a negative relationship exists between the number of individuals per unit area and mean individual mass (Guiñez \& Castilla 2001). As a result, competition in the form of severe crowding affects the morphological characteristics and the energy/tissue allocation of $P$. praeputialis (Guiñez \& Castilla 2001). Experiments analyzing competition for space between the introduced $P$. praeputialis and the native mussel Perumytilus purpuratus in Antofagasta Bay have shown that the tunicate significantly affects native rocky intertidal biota, as well as several ecological processes. 


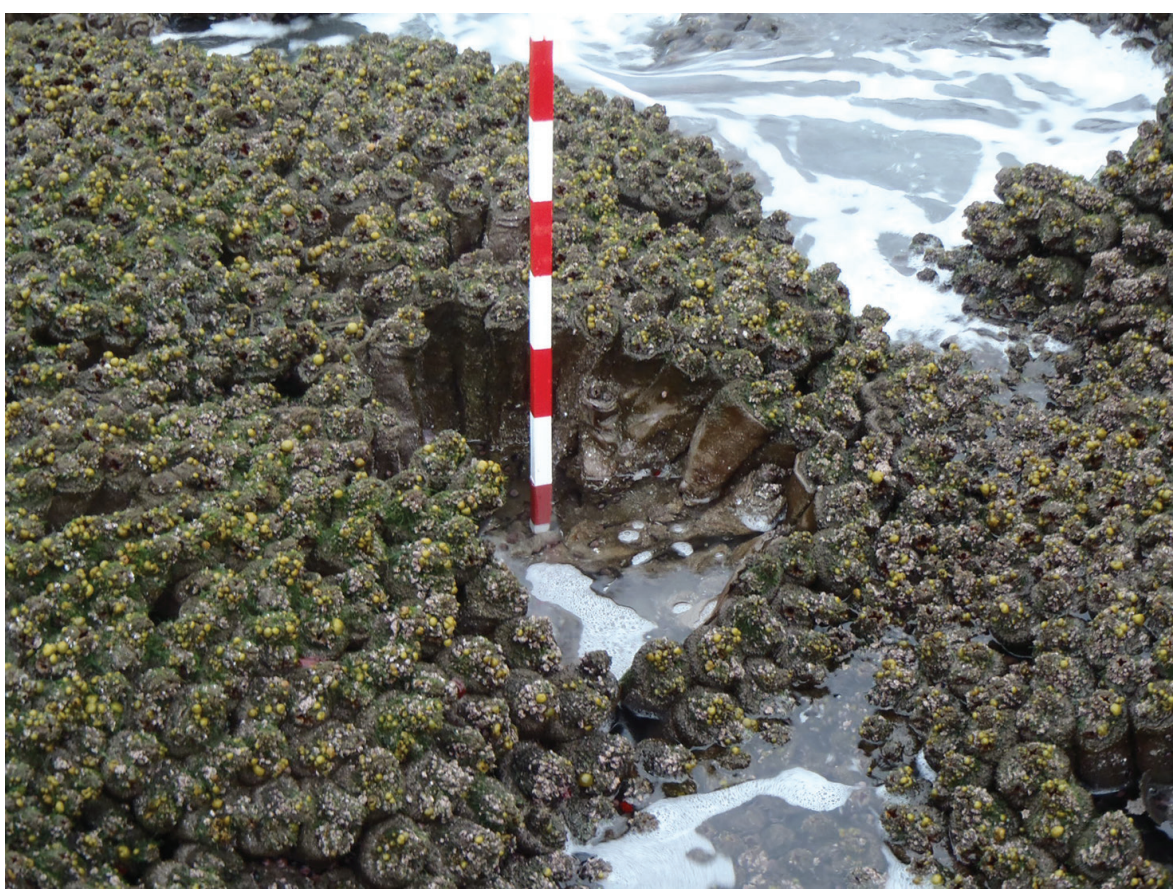

Figure 6 Dense aggregations of Pyura praeputilalis in La Rinconada $\left(23^{\circ} 28^{\prime} 16.41^{\prime \prime} \mathrm{S}, 70^{\circ} 30^{\prime} 47.83^{\prime \prime} \mathrm{W}\right)$, Chile. A bar with red and white sections (10 centimetres each) was positioned for scale.

For example, Pyura praeputialis has completely modified the intertidal zonation pattern of the bay by monopolizing the low and mid rocky intertidal zones, constraining the distribution of the native mussel to the mid-upper intertidal fringe (Castilla et al. 2004a, Caro et al. 2011, Manríquez et al. 2016). In Antofagasta Bay, Ortiz et al. (2013), analized rocky intertidal communities using Ecopath, Ecosim and Loop Analysis (Levins, 1974) to better understand the properties of keystone species (e.g. biomass, food consumption) and concluded that $P$. praeputialis is not a superior bioengineer compared to the kelp Lessonia nigrescens. In fact, the model indicated that these two bioengineer species hosted ecologically-similar species but relied on different ecological processes to carry out their ecosystem role.

Another consequence of dominance by members of the P.s.s.c. is the creation of habitat structure that allows a diverse associated community to thrive. In South Africa, 64 intertidal and 61 subtidal taxa of benthic macroinvertebrates, representing 10 phyla, were associated with aggregations of Pyura stolonifera (Fielding et al. 1994). Similar research on aggregations of $P$. praeputialis in Antofagasta Bay reported 96 associated benthic invertebrate species (Castilla et al. \& Camaño 2001), with polychaetes, decapods and bivalves being the most speciose (see Cerda \& Castilla 2001). In addition to epifauna, amphipods, copepods and nemerteans may be present inside the branchial sac of large individuals (e.g. Oldewage 1994, Dalby 1996). Van Driel \& Steyl (1978) showed that in Algoa Bay (South Africa), the composition of communities associated with P. stolonifera was determined by levels of wave exposure. Similarly, Ramírez \& Mena (1984) found differences in the distribution and abundance of macroalgae that grow on top of Pyura praeputialis aggregations in Antofagasta Bay across different levels of wave exposure. Although high densities of Ulva spp. are frequently observed growing on top of P. praeputialis (see Castilla et al. 2014), the presence of algae does not appear to affect the ascidian (Castilla et al. 2004b). The density of P. praeputialis individuals also affects the composition of associated communities, with clumped and sparse $P$. praeputialis individuals having different alga- and invertebrate-associated assemblages 


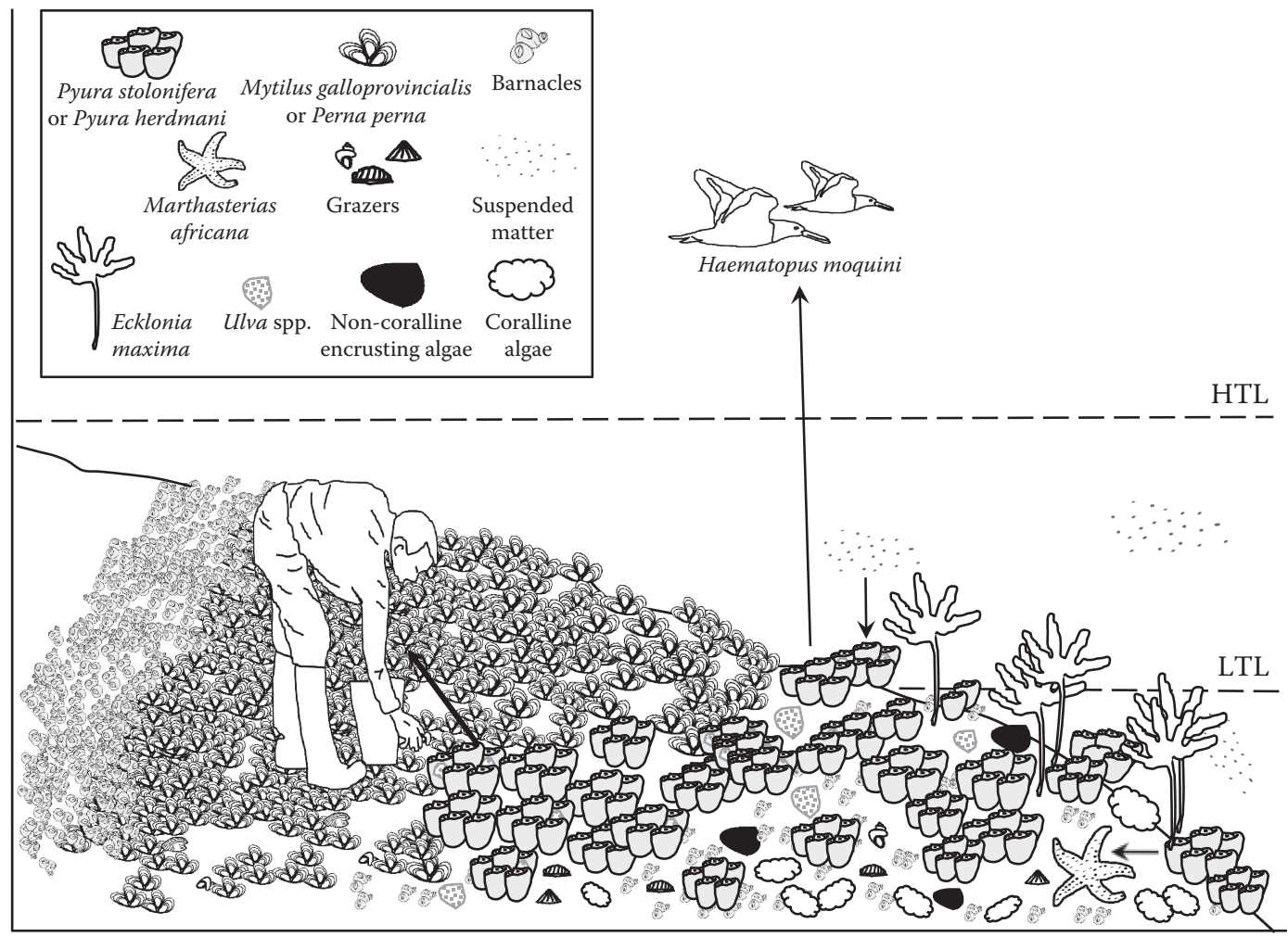

Figure 7 Food web and energy transfer on intertidal rocky shores in South Africa (southwestern coast, native range) where members of the Pyura stolonifera species complex can be found. Low tidal level (LTL) and high tidal level (HTL) are indicated. (Continued)

(Monteiro et al. 2002). Coralline algae and the limpet Cellana sp. are typically found in low-density aggregations of Pyura praeputialis, whereas species of whelks are more common in denser aggregations (Monteiro et al. 2002).

Predation upon members of the P.s.s.c. has rarely been studied (see Alvarado 2004). In Chile, apart from human harvesting (see below), the main intertidal predators are the sunstar Heliaster helianthus (Castilla et al. 2013) and the muricid gastropod Concholepas concholepas (Alvarado 2004), which both appear to regulate populations of Pyura praeputialis in the lower intertidal zone (Castilla et al. 2004a) (Figure 7). Further, the oystercatcher Haematopus palliatus pitanay is also an active predator of Pyura praeputialis in Chile (Pacheco \& Castilla 2001, Goss-Custard et al. 2006) (Figure 7). In Australia, the triton shell Cabestana spengleri and the sooty oystercatcher Haematopus fuliginosus have been reported as preying on Pyura praeputialis (Schultz 1989, Fairweather 1991, Chafer 1992). Finally, in South Africa, known predators include the oystercatcher Haematopus moquini and the seastar Marthasterias africana (Wright et al. 2016) (Figure 7), but more work is needed to determine the extent of their predatory role in intertidal communities.

Apart from competition and predation, two additional factors can negatively affect the population dynamics of the P.s.s.c.. The first is mass mortality, as reported for Pyura stolonifera along the South African coast (Hanekom et al. 1999, Hanekom 2013). Such mortalities were suspected to occur as a result of infection by an unidentified microbe, potentially as an indirect result of abnormally high temperatures (Hanekom 2013). The second factor is patch dynamics that are directly influenced by mechanical forces. Intertidal and subtidal aggregations of $P$. praeputalis are 


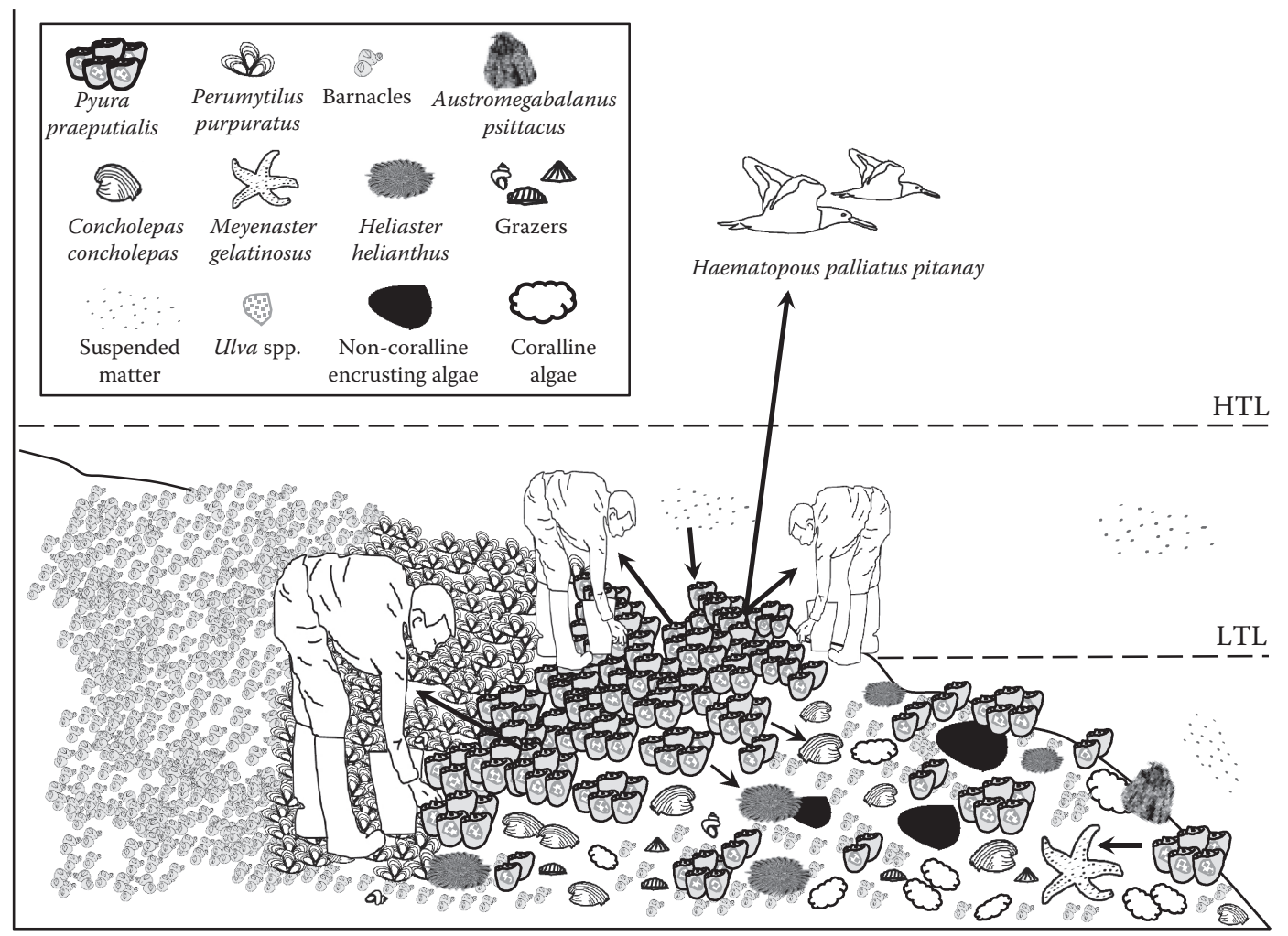

Figure 7 (Continued) Food web and energy transfer on intertidal rocky shores in Chile (Antofagasta Bay, introduced range) where members of the Pyura stolonifera species complex can be found. Low tidal level (LTL) and high tidal level (HTL) are indicated.

constantly exposed to removal by wave action. An important patch-filling mechanism is propagule retention, which increases recruitment in the patch-border zone next to adults (Alvarado et al. 2001).

\section{Invasion biology and the Pyura stolonifera species complex}

Species that are dominant in their native habitat are expected to have a particularly high likelihood of becoming invasive once established elsewhere (Simberloff 2010). Therefore, understanding dominance is particularly important for predicting the changes in ecosystem structure and function caused by biological invasions. Members of the P.s.s.c. dominate intertidal and subtidal areas in their native ranges, and when these species are introduced to new areas, they can strongly alter local communities. Introductions of members of the P.s.s.c. are being reported with increasing frequency, including the colonization of the northern part of New Zealand's North Island by Pyura doppelgangera (Hayward \& Morley 2009, Fletcher 2014) and the recent introduction of P. herdmani to northwestern Spain (X. Turon, personal communication).

A growing debate exists in the literature around the concept of invasiveness and the impact of invasive species on recipient communities (see Cronon 1983, Katz 1992, Soulé 1995, Jordan 2000, Katz 2000, Cafaro 2001, Castilla \& Neill 2009, Simberloff 2012, Simberloff \& Vitule 2014). This debate includes conceptual aspects such as understanding what is 'native', 'harmful' or 'wild', and even philosophical aspects; for example whether non-indigenous sentient (vertebrate) or nonsentient species (e.g. invertebrates, plants, fungi) have intrinsic value (see Varner 1990, 1998, Justus et al. 2009). Some non-indigenous species are considered to be innocuous, while others can have 
dramatic ecological effects (although the latter may have critical economic value for humans, e.g. in terms of food security). Non-indigenous marine organisms can have positive, neutral or negative impacts on humans (Castilla \& Neill 2009, Manríquez et al. 2016). For example, the non-indigenous intertidal macroalgae Porphyra linearis, Pyropia pseudolinearis (=Porphyra pseudolinearis) and Mastocarpus papillatus are commercially important resources in Chile, as they are extracted by small-scale (artisanal) fishermen, and as yet no negative ecological impact has been reported. Similarly, both Pyura praeputialis and subtidal red algae of the genus Gracilaria are introduced species in Chile but have not yet caused adverse economic effects (Castilla et al. 2002, Castilla et al. 2014, Manríquez et al. 2016). In South Africa, the introduced mussel Mytilus galloprovincialis has been farmed for decades (Heasman et al. 1998), but even though this species is now of considerable economic importance it dominates extensive stretches of the South African coastline, causing drastic ecological changes to native communities (Robinson et al. 2005). Another example of dominant non-indigenous species causing harm to natural communities is Pyura praeputialis in Antofagasta Bay. This species has reduced the abundance of native species of mussels through displacement by competition for space (Castilla 1998, Castilla \& Guiñez 2000, Castilla et al. 2004a, Castilla 2008, Caro et al. 2011, Castilla et al. 2014, Manríquez et al. 2016). In turn, however, the presence of this introduced species has resulted in an increase of overall local biodiversity (i.e. an increase in macroinvertebrate richness) via the provision of a new habitat (Castilla et al. 2004b, Castilla et al. 2005).

Once a new geographic area is colonized, establishment success depends on the inability of the resident community to repel newcomers (Rius et al. 2014b). Specifically, certain types of habitats (e.g. marine hard infrastructure, Airoldi et al. 2015) and community attributes (e.g. levels of native species diversity, Crutsinger et al. 2008) may facilitate biological invasions in some regions but not others. This is illustrated by considerable differences in the colonization success of the nonindigenous populations of Pyura doppelgangera (Teske et al. 2014). In the North Island of New Zealand this species was introduced less than 20 years ago (Hayward \& Morley 2009) and has now spread along $100 \mathrm{~km}$ of exposed rocky shores (Fletcher 2014). In contrast, introduced populations of the same species in two regions of the Australian mainland (Adelaide in South Australia, and Corner Inlet in Victoria) have failed to expand their ranges beyond the immediate points of introduction. Taxonomic and genetic evidence suggests that this species has recently been introduced to mainland Australia (Kott 1952, Teske et al. 2014) from northern Tasmania. Both Adelaide and Corner Inlet lack rocky shores and are dominated by sandy shores (Bowman \& Harvey 1986), with artificial structures such as jetties and piers representing the only habitat suitable for settlement. Such marine infrastructures are spaced a few kilometres apart and thus large gaps of sandy beach seem to limit connectivity among suitable habitats. Small-scale dispersal has been assessed in the $P$. doppelgangera population of the Adelaide metropolitan area and revealed high levels of selfrecruitment, with most larvae settling on the structure occupied by their parents (Teske et al. 2015). This is also consistent with findings suggesting effective gamete retention mechanisms and spawning synchrony of P. praeputialis in southeastern Australia (Marshall 2002).

The short larval duration typical of solitary ascidians (Figure 5) considerably reduces colonization success when substrata suitable for settlement are located far from one another, and suggests that Pyura doppelgangera will only spread rapidly where habitat is more continuous. In New Zealand, the sea star Stichaster australis and a whelk of the genus Cabestana prey upon the abundant new food resource provided by Pyura doppelgangera (Fletcher 2014). However, such biotic resistance effects are clearly insufficient to counteract the invasion of this ascidian species. Localized removal of $P$. doppelgangera patches have been conducted by local communities, but it is likely to prove too late for the complete eradication of this invasive species.

Cases of naturalization (i.e. species that are able to self-sustain populations but that have failed to spread beyond the immediate point of introduction, Richardson et al. 2000) have also been reported in the P.s.s.c. For example, while Pyura praeputialis is found along thousands of kilometres of rocky shore in its native habitat in Australia, the Chilean distribution is restricted to a single 
bay (Clarke et al. 1999, Castilla \& Guiñez 2000, Castilla et al. 2002). Other examples of limited distribution include those of $P$. dalbyi in Western Australia (Teske et al. 2011) and $P$. doppelgangera in mainland Australia (Teske 2014, Teske et al. 2015).

\section{Human exploitation and conservation of the Pyura stolonifera species complex}

Human activities such as rocky intertidal harvesting and trampling are well-known stressors of several marine taxa including algae (Bally \& Griffiths 1989, Castilla \& Bustamante 1989, Castilla et al. 2007a) and various invertebrates (Castilla \& Durán 1985, Roy et al. 2003, Smith \& Murray 2005, Rius et al. 2006). Although human exploitation of intertidal resources targets a wide range of species (Moreno et al. 1984, Lasiak 1991, Keough et al. 1993, Castilla 1999), dominant species (e.g. mussels and tunicates) are often an important proportion of the overall catch (Kyle et al. 1997, Rius \& Cabral 2004). This is not surprising as the gregarious nature of these organisms allows maximization of the catch. The selective removal of large adults in limited quantities may allow sustainable exploitation of intertidal resources (as is sometimes seen in subsistence exploitation, Castilla et al. 2014), but human harvesting is often unrestrained and can be a major conservation threat to intertidal communities.

Humans harvest members of the P.s.s.c. for subsistence exploitation and/or recreational activities (e.g. bait collection). Such activities have been reported in Australia (Otway 1989, Fairweather 1991, Kingsford et al. 1991, Chapman \& Underwood 1994, Monteiro et al. 2002), South Africa (Kyle et al. 1997) and Chile (Castilla et al. 2004a, Castilla et al. 2014, Manríquez et al. 2016). Fairweather (1991) studied the exploitation of Pyura praeputialis at seven intertidal sites in New South Wales, Australia, showing that changes in density of $P$. praeputialis were temporally asynchronous among sites but that $P$. praeputialis recovery was consistently slow. The study concluded that the population dynamics of $P$. praeputialis are modulated by human harvesting, episodic storms and recruitment patterns. Monteiro et al. (2002) studied habitat structure in patches of P. praeputialis in Sydney, Australia, where fishermen collect this species for bait, and found that changes to the structure of these patches resulted in changes in the composition of associated biota. The authors identified 19 algal and 45 invertebrate species in habitats provided by $P$. praeputialis, and species assemblages differed significantly between sparse and dense patches. In South Africa, P. herdmani is heavily exploited by intertidal food-gatherers (Fielding et al. 1994), as well as anglers who collect this species for bait. Along some parts of the South African coast $P$. herdmani is the second most important harvested species (after mussels) (Kyle et al. 1997). In Chile, P. praeputialis is considered a delicacy and has a high market value, and studies indicate that the rate of extraction by professional tunicate gatherers can be up to 750 individuals $\mathrm{h}^{-1}$ during low tide (Castilla et al. 2014, Manríquez et al. 2016). The harvesting of $P$. praeputialis is in fact so continuous and intense that it impairs recruitment. The shrinking of $P$. praeputialis aggregations in certain sites has allowed mussels to recover intertidal dominance (Castilla et al. 2014, Manríquez et al. 2016).

Reductions of intertidal aggregations of members of the P.s.s.c. can significantly affect the associated intertidal community (Fielding et al. 1994, Cerda \& Castilla 2001, Monteiro et al. 2002, Castilla et al. 2004b, Manríquez et al. 2016). In Chile, the crevices and gaps between individuals of Pyura praeputialis create microhabitats for the settlement of the species Concholepas concholepas, a commercially important gastropod (Castilla \& Jerez 1986, Castilla et al. 1998, Castilla 1999, Castilla \& Defeo 2001, Manríquez et al. 2008, Gelcich et al. 2017), and they are used by females of C. concholepas to lay thousands of egg capsules during the reproductive season (authors' unpublished data). In addition, individuals of $C$. concholepas and Octopus mimus have traditionally been collected from aggregations of Pyura praeputialis during low tide. However, overexploitation of 
$P$. praeputialis during the past decade has resulted in a considerable decrease in the number of these associated species (authors' unpublished data). Similarly, the scarcity of $P$. stolonifera and $P$. herdmani along some sections of the South African coast may be an indication of overharvesting (e.g. Kyle et al. 1997, Majiza \& Lasiak 2010). Future repopulation initiatives may be key for restoring ecosystem functioning, as these aggregations play an important role as bioengineers (Castilla et al. 2001, Castilla et al. 2004b). Considering that ecological dominance influences many fundamental aspects of ecosystem health, such as coexistence and metacommunity dynamics (Hillebrand et al. 2008), human activities reducing the dominance of members of the P.s.s.c. are likely to result in alterations of biodiversity patterns.

\section{Conclusions and future research directions}

Dominant species are superior competitors that often generate exceptional levels of biomass. Although many attributes (e.g. gregariousness, sessile life strategy, broadcast spawning) may be linked to ecological dominance (Figure 2), it cannot be readily explained by any specific combination of traits (Figure 3). The presence of dominant sessile invertebrates generally increases habitat complexity, directly benefiting a wide range of associated biota. Therefore, dominant species are key components for the conservation of biodiversity and ecosystem functioning along rocky shores.

Although knowledge of ecological dominance has been accumulating for decades, more research is needed to understand fully some of the underlying ecological and evolutionary mechanisms. For example, little is known about how kin selection affects gregariousness, and there is limited information on possible links between Allee effects and ecological dominance. To date, there is little empirical evidence for Allee effects in natural populations (Gascoigne \& Lipcius 2004), and studies are particularly scarce in the context of dominant species.

This review focused on members of the P.s.s.c. as a key example for the study of ecological dominance. Among many consequences that derive from the presence of these dominant species, creation of architectural complexity is one of the most striking, as it influences the hydrodynamics of intertidal zones, ameliorates physical stress and creates habitat for a wide range of associated species. Other aspects remain largely unexplored, however. For example, there is as yet no information on the impact of the P.s.s.c. on planktonic communities. The high rates of filtration and particle retention achieved by the members of the P.s.s.c. suggest that they may extract massive amounts of suspended particles from seawater (Klumpp 1984, Seiderer \& Newell 1988). This, together with their aggregated nature and large adult size, strongly suggest that these species have an important role in ecosystems. High clearance rates that significantly alter seston composition and reduce food availability may directly affect adult survival, growth and reproductive potential of competing or subordinate species, such as mussels and barnacles. Another unexplored consequence of such high filtration capacity is the consumption of heterospecific gametes and larvae. Studies have assessed the role of cannibalism by members of the P.s.s.c. and found that it reduces the conspecific larval pool. However, little is known about how such feeding may influence the abundance and distribution of heterospecific gametes and larvae. Species that could be directly displaced include suspension-feeders but also primary producers (e.g. seaweeds). Thus, possible impacts of the presence of these dominant ascidians could go beyond a specific trophic level, and influence entire food chains. A negative association between tunicate abundance and the settlement of mussel larvae has been found (LeBlanc et al. 2007), which suggests tunicate predation on mussel larvae, as well as a reduction of available food particles. This may have been the mechanism through which the invasive population of Pyura praeputialis in Antofagasta Bay outcompeted the native mussel species Perumytilus purpuratus (Castilla et al. 2004a, Castilla et al. 2014). Finally, the multiphasic life cycle of the members of the P.s.s.c. (Figure 5) implies that the size and type of particles consumed by each life-history stage (i.e. postmetamorph, juvenile and adult) vary, so the study of dietary shifts (see Sherrard \& LaBarbera 2005) may reveal important insights into this possible form of food 
competition. Taken together, filtration capacity, when fully investigated, may reveal key aspects facilitating the establishment and maintenance of dense aggregations of these dominant species.

Comprehensive information is available on the intertidal distribution, population structure, biomass, energy/tissue allocation and phenotypic traits of the members of the P.s.s.c., especially from Antofagasta Bay, Chile (e.g. Clarke et al. 1999, Castilla et al. 2000). The restricted distribution of Pyura praeputialis in South America (a range of only about $70 \mathrm{~km}$; Castilla et al. 2002) and the high densities attained there (intertidal belts over $10 \mathrm{~m}$ wide, with the highest densities towards the centre of the belt) makes Antofagasta Bay a unique location to study ecological aspects of this species. However, our present ecological knowledge is limited to studies of $P$. praeputialis and $P$. stolonifera. Further research is therefore required to study the ecology of the remaining members of the P.s.s.c., as well as to understand the influence of coastal geography and oceanography on ecological dominance. Nearshore larval retention of $P$. praeputialis has been reported in Antofagasta Bay (Castilla \& Largier 2002), but similar studies are needed in the native range. Distances between suitable habitats may be too large to be crossed by larval transport, particularly when oceanographic conditions are not favourable, and consequently, self-recruitment seems to be the norm (Teske et al. 2015). Regions where the effects of geography and oceanography could be tested include False Bay in South Africa and the coastline around Adelaide in Australia. Taken together, it remains uncertain how geographic and oceanographic singularities affect ecological dominance.

In order to study ecological dominance, a detailed understanding of the taxonomy and evolutionary history of the studied organism is required. For example, failing to correctly identify cryptic species or hybrids could lead to erroneous interpretation of ecological data. For the members of the P.s.s.c., the combined study of morphological and genetic data has greatly facilitated the resolution of phylogenetic relationships (Teske et al. 2011, Rius \& Teske 2013). However, numerous challenges remain. First, it is presently not established whether the species complex is reciprocally monophyletic. Thus, more work is needed to understand whether all its members have arisen from a single ancestor, or whether the inclusion of some species is merely an artefact of similar morphology. For example, the phylogenetic placement of Pyura dalbyi is poorly resolved (Teske et al. 2011), and it is possible that this species is more closely related to the morphologically very different $P$. spinifera (Quoy \& Gaimard 1834). It is also uncertain whether any of the presently-accepted species comprise additional 'cryptic' species that should be scientifically described. Phylogenetic data based on mitochondrial DNA sequences indicate that $P$. herdmani comprises four reciprocally monophyletic genetic lineages (Teske et al. 2011). One lineage occurs in northwestern Africa, one in subtropical/ tropical southern Africa, and two lineages have overlapping ranges in temperate southern Africa. While these lineages may be morphologically difficult to distinguish, different geographical ranges or habitat preferences support the hypothesis that they may be different species (see Rius \& Teske 2011). Of the temperate southern African populations, one has a sister-taxon relationship with the northwest African population of $P$. herdmani and has so far been exclusively found on rocky shores, while the other also occurs on sandy sediments. Given that $P$. herdmani can hybridize with $P$. stolonifera (Rius \& Teske 2013), it cannot be ruled out that hybridization is also common among the individual southern African lineages of $P$. herdmani, which would considerably complicate attempts at resolving their taxonomy. The existence of hybrids in regions where multiple species coexist (i.e. southern Africa and southeastern Australia) could provide important insights into understanding recent range expansions. Human activities are known to facilitate interbreeding among divergent lineages (Chunco 2014, Vallejo-Marín \& Hiscock 2016), which may create hybrids with enhanced ability to colonize new habitats (Ruis \& Darling 2014).

Genetic data have been particularly useful in confirming the non-indigenous status of populations of the members of the P.s.s.c. Genetic evidence often falls into two categories: 1) lack of genetic differentiation among non-indigenous populations that contrasts with well-defined native population structure, and 2) recent divergence between native and introduced ranges (on the basis of molecular dating) since the start of human-mediated transoceanic transport. In addition, circumstantial 
evidence for the non-indigenous status of a particular population could include small distribution ranges (e.g. limited to harbours as most likely points of introduction, Carlton \& Geller 1993) and settlement on marine infrastructures in regions that lack rocky shores. DNA sequence data have been used to identify the lack of genetic differentiation among introduced populations that are separated by vast distribution gaps. For example, a genetic study of Pyura praeputialis samples collected in Chile revealed that these were genetically indistinguishable from eastern Australian populations (Castilla et al. 2002), and all mtDNA haplotypes found in the single Western Australian population of $P$. dalbyi were also found in southeastern Australia (Teske et al. 2011). The use of polymorphic microsatellites can be much more informative than sequence data in revealing the colonization history of non-indigenous populations (e.g. Rius et al. 2012). The high mutation rate of these genetic markers make them suitable for distinguishing ancient natural colonization events from introductions that have occurred since humans started navigating the seas. For example, microsatellite data confirmed that all non-Tasmanian populations of $P$. doppelgangera diverged from closely related northern Tasmanian populations no more than a few hundred years ago (Teske et al. 2014). Genetic data able to provide information on recent changes are thus required for understanding recent colonization events by these dominant species. For example, many uncertainties remain concerning the introduction of P. praeputialis from Australia to Chile. Fine-scale and temporal genetic studies have the potential to not only reveal important information on the colonization history of this species, but also to provide key insights into the community effects of this species over time.

Members of the P.s.s.c. are often reported as introduced species around the world (Figure 4) but few studies have focused on reconstructing invasion routes or identifying source populations or the presence of recurrent introductions. A particularly interesting example is the recent introduction of Pyura doppelgangera in New Zealand (Hayward \& Morley 2009), where it has spread across continuous rocky shores, replacing native assemblages. Since limited information is available to date (Rius \& Teske 2013), a multilocus genetic or genomic study would help to explain why and how this invasion is particularly successful. New introductions by members of the P.s.s.c. provide unplanned replicated experiments to study the consequences of ecological dominance for rocky shore ecosystems.

\section{Acknowledgements}

We are grateful to Steve Hawkins, Louise Firth and Hanna Schuster for inviting us to submit this review, as well as an anonymous reviewer for insightful comments that helped improve the final version. We are grateful to John Largier for discussion during the early planning of this review. MR acknowledges ASSEMBLE (an EU FP7 research infrastructure initiative comprising a network of marine research stations) for awarding a grant to conduct research at the 'Estación Costera de Investigaciones Marinas-Las Cruces', Chile. JCC is grateful for support from the project entitled 'Núcleo Milenio en Conservación Marina CCM RC 130004, Iniciativa Científica Milenio, Ministerio de Economía' de Chile and the 'Minera Escondida Ltda' for long-term logistic and financial support. PHM acknowledges the National Fund for Scientific and Technological Development (FONDECYT) of Chile for the financial support that has allowed him to conduct, through several grants, research activities in Antofagasta Bay from year 2000. This work is based upon research supported by the South African Research Chairs Initiative of the Department of Science and Technology and the National Research Foundation.

\section{References}

Aiken, C.M. \& Navarrete, S.A. 2014. Coexistence of competitors in marine metacommunities: environmental variability, edge effects, and the dispersal niche. Ecology 95, 2289-2302.

Airoldi, L. Turon, X., Perkol-Finkel, S. \& Rius, M. 2015. Corridors for aliens but not for natives: effects of marine urban sprawl at a regional scale. Diversity and Distributions 21, 755-768. 
Almany, G.R., Berumen, M.L., Thorrold, S.R., Planes, S. \& Jones, G.P. 2007. Local replenishment of coral reef fish populations in a marine reserve. Science 316, 742-744.

Alvarado, J.L. 2004. Patrones de distribución de organismos intermareales en la Bahía de Antofagasta: patrones simples y causas complejas. PhD thesis, Pontificia Universidad Católica de Chile.

Alvarado, J.L. \& Castilla, J.C. 1996. Tridimensional matrices of mussels Perumytilus purpuratus on intertidal platforms with varying wave forces in central Chile. Marine Ecology Progress Series 133, 135-141.

Alvarado, J.L., Pinto, R., Marquet, P., Pacheco, C., Guiñez, R. \& Castilla, J.C. 2001. Patch recolonization by the tunicate Pyura praeputialis in the rocky intertidal of the Bay of Antofagasta, Chile: evidence for self-facilitation mechanisms. Marine Ecology Progress Series 224, 93-101.

Astorga, M.P., Guiñez, R. \& Castilla, J.C. 2009. Genetic divergence in the ascidian Pyura praeputialis (= Pyura stolonifera) $($ Heller, 1878) from mainland Australia and Tasmania. Papers and Proceedings of the Royal Society of Tasmania 143, 101-104.

Babcock, R. \& Keesing, J. 1999. Fertilization biology of the abalone Haliotis laevigata: laboratory and field studies. Canadian Journal of Fisheries and Aquatic Sciences 56, 1668-1678.

Baird, A.H. \& Hughes, T.P. 2000. Competitive dominance by tabular corals: an experimental analysis of recruitment and survival of understorey assemblages. Journal of Experimental Marine Biology and Ecology 251, 117-132.

Baird, D., Asmus, H. \& Asmus, R. 2004. Energy flow of a boreal intertidal ecosystem, the Sylt-Rømø Bight. Marine Ecology Progress Series 279, 45-61.

Bak, R.P.M., Joenje, M., de Jong, I., Lambrechts, D.Y.M. \& Nieuwland, G. 1998. Bacterial suspension feeding by coral reef benthic organisms. Marine Ecology Progress Series 175, 285-288.

Bally, R. \& Griffiths, C.L. 1989. Effects of human trampling on an exposed rocky shore. International Journal of Environmental Studies 34, 115-125.

Bayne, B.L. 1964. Primary and secondary settlement in Mytilus edulis L. (Mollusca). Journal of Animal Ecology 33, 513-523.

Berec, L., Angulo, E. \& Courchamp, F. 2007. Multiple Allee effects and population management. Trends in Ecology \& Evolution 22, 185-191.

Berkley, H.A., Kendall, B.E., Mitarai, S. \& Siegel, D.A. 2010. Turbulent dispersal promotes species coexistence. Ecology Letters 13, 360-371.

Bertness, M.D. \& Grosholz, E. 1985. Population dynamics of the ribbed mussel, Geukensia demissa: the costs and benefits of an aggregated distribution. Oecologia 67, 192-204.

Bertness, M.D. \& Leonard, G.H. 1997. The role of positive interactions in communities: lessons from intertidal habitats. Ecology 78, 1976-1989.

Bone, Q., Carré, C. \& Chang, P. 2003. Tunicate feeding filters. Journal of the Marine Biological Association of the UK 83, 907-919.

Bowman, G. \& Harvey, N. 1986. Geomorphic evolution of a Holocene beach-ridge complex, LeFevre Peninsula, South Australia. Journal of Coastal Research 2, 345-362.

Branch, G.M. 1984. Competition between marine organisms: ecological and evolutionary implications. Oceanography and Marine Biology: An Annual Review 22, 429-593.

Brown, J.H. \& Maurer, B.A. 1986. Body size, ecological dominance and Cope's rule. Nature 324, 248-250.

Bruno, J.F., Stachowicz, J.J. \& Bertness, M.D. 2003. Inclusion of facilitation into ecological theory. Trends in Ecology \& Evolution 18, 119-125.

Cafaro, P. 2001. For a grounded conception of wilderness and more wilderness on the ground. Ethics and the Environment 6, 1-17.

Carlton, J.T. \& Geller, J.B. 1993. Ecological roulette: the global transport of nonindigenous marine organisms. Science 261, 78-82.

Caro, A.U., Guiñez, R., Ortiz, V. \& Castilla, J.C. 2011. Competition between a native mussel and a nonindigenous invader for primary space on intertidal rocky shores in Chile. Marine Ecology Progress Series 428, 177-185.

Castilla, J.C. 1998. Las comunidades intermareales de la Bahía San Jorge: estudios de linea base y el programa ambiental de Minera Escondida Ltda. en Punta Coloso. In Mineria del Cobre, Ecologia y Ambiente Costero, D. Arcos (ed.). Editorial Anibal Pinto SA, 221-244.

Castilla, J.C. 1999. Coastal marine communities: trends and perspectives from human exclusion experiments. Trends in Ecology \& Evolution 14, 280-283. 
Castilla, J.C. 2008. Fifty years from the publication of the first two papers on Chilean rocky intertidal assemblages: honoring Professor Eric R. Guiler. Revista de Biología Marina y Oceanografía 43, 457-467.

Castilla, J.C. \& Bustamante, R.H. 1989. Human exclusion from rocky intertidal of Las Cruces, central Chile: effects on Durvillaea antarctica (Phaeophyta, Durvilleales). Marine Ecology Progress Series 50, 203-214.

Castilla, J.C., \& Camaño, A. 2001. El piure de Antofagasta, Pyura praeputialis (Heller, 1878): un competidor dominante e ingeniero de ecosistemas. In Sustentabilidad de la Biodiversidad. K. Alveal \& T. Antezana (eds). Universidad de Concepcíon, Chile, 719-729.

Castilla J.C., Campos, M.A. \& Bustamante, R.H. 2007a. Recovery of Durvillaea antarctica (Durvilleales) inside and outside Las Cruces Marine Reserve. Ecological Applications 17, 1511-1522.

Castilla, J.C., Collins, A.G., Meyer, C.P., Guiñez, R. \& Lindberg, D.R. 2002. Recent introduction of the dominant tunicate, Pyura praeputialis (Urochordata, Pyuridae) to Antofagasta, Chile. Molecular Ecology 11, 1579-1584.

Castilla, J.C. \& Defeo, O. 2001. Latin-American benthic shellfisheries: emphasis on co-management and experimental practices. Reviews in Fish Biology and Fisheries 11, 1-30.

Castilla, J.C. \& Durán, L.R. 1985. Human exclusion from the rocky intertidal zone of central Chile: the effects on Concholepas concholepas (Gastropoda). Oikos 45, 391-399.

Castilla, J.C. \& Guiñez, R. 2000. Disjoint geographical distribution of intertidal and nearshore benthic invertebrates in the Southern Hemisphere. Revista Chilena de Historia Natural 73, 585-603.

Castilla, J.C., Guiñez, R., Alvarado, J.L., Pacheco, C. \& Varas, M. 2000. Distribution, population structure, population biomass and morphological characteristics of the tunicate Pyura stolonifera in the Bay of Antofagasta, Chile. Marine Ecology 21, 161-174.

Castilla, J.C., Guiñez, R., Caro, A.U. \& Ortiz, V. 2004a. Invasion of a rocky intertidal shore by the tunicate Pyura praeputialis in the Bay of Antofagasta, Chile. Proceedings of the National Academy of Sciences of the USA 101, 8517-8524.

Castilla, J.C. \& Jerez, G. 1986. Artisanal fishery and the development of a data base for managing the loco (Concholepas concholepas) in Chile. Canadian Journal of Fisheries and Aquatic Sciences 92, 133-139.

Castilla, J.C., Lagos, N.A. \& Cerda, M. 2004b. Marine ecosystem engineering by the alien ascidian Pyura praeputialis on a mid-intertidal rocky shore. Marine Ecology Progress Series 268, 119-130.

Castilla, J.C. \& Largier, J. 2002. The Oceanography and Ecology of the Nearshore and Bays in Chile. Ediciones Universidad Católica de Chile.

Castilla, J.C., Manríquez, P., Alvarado, J., Rosson, A., Pino, C., Soto, R., Oliva, D. \& Defeo, O. 1998. Artisanal caletas as units of production and co-managers of benthic invertebrates in Chile. Canadian Journal of Fisheries and Aquatic Sciences 125, 407-413.

Castilla, J.C., Manríquez, P.H., Delgado, A., Ortiz, V., Jara, M.E. \& Varas, M. 2014. Rocky intertidal zonation pattern in Antofagasta, Chile: invasive species and shellfish gathering. PLoS ONE 9, e110301.

Castilla, J.C., Manríquez, P.H., Delgado, A.P., Gargallo, L., Leiva, A. \& Radic, D. 2007b. Bio-foam enhances larval retention in a free-spawning marine tunicate. Proceedings of the National Academy of Sciences of the USA 104, 18120-18122.

Castilla, J.C., Navarrete, S.A., Manzur, T. \& Barahona, M. 2013. Heliaster helianthus. In Starfish, J.M. Lawrence (ed.). Baltimore, USA: Johns Hopkins University Press, 153-160.

Castilla, J.C. \& Neill, P.E. 2009. Marine bioinvasions in the southeastern Pacific: status, ecology, economic impacts, conservation and management. In Biological Invasions in Marine Ecosystems, G. Rilov \& J.A. Crooks (eds). Berlin \& Heidelberg: Springer-Verlag, 439-457.

Castilla, J.C., Uribe, M., Bahamonde, N., Clarke, M., Desqueyroux-Faúndez, R., Kong, I., Moyano, H., Rozbaczylo, N., Santelices, B., Valdovinos, C. \& Zavala, P. 2005. Down under the southeastern Pacific: marine non-indigenous species in Chile. Biological Invasions 7, 213-232.

Cerda, M. \& Castilla, J.C. 2001. Diversity and biomass of macro-invertebrates in intertidal matrices of the tunicate Pyura praeputialis (Heller, 1878) in the Bay of Antofagasta, Chile. Revista Chilena de Historia Natural 74, 841-853.

Cerrano, C. \& Bavestrello, G. 2009. Mass mortalities and extinctions. In Marine Hard Bottom Communities, M. Wahl (ed.). Berlin \& Heidelberg: Springer-Verlag, 295-307.

Chafer, C.J. 1992. Ascidian predation by the sooty oystercatcher Haematopus fuliginosus: further observation. Stilt 20, 20-21. 
Chapman, M.G. \& Underwood, A.J. 1994. Dispersal of the intertidal snail, Nodilittorina pyramidalis, in response to the topographic complexity of the substratum. Journal of Experimental Marine Biology and Ecology 179, 145-169.

Chunco, A.J. 2014. Hybridization in a warmer world. Ecology and Evolution 4, 2019-2031.

Clapham, M.E., Bottjer, D.J., Powers, C.M., Bonuso, N., Fraiser, M.L., Marenco, P.J., Dornbos, S.Q. \& Pruss, S.B. 2006. Assessing the ecological dominance of Phanerozoic marine invertebrates. Palaios 21, 431-441.

Clarke, M., Ortiz, V. \& Castilla, J.C. 1999. Does early development of the chilean tunicate Pyura praeputialis (Heller, 1878) explain the restricted distribution of the species? Bulletin of Marine Science $\mathbf{6 5}, \mathbf{7 4 5 - 7 5 4 .}$

Cole, V.J. \& McQuaid, C.D. 2010. Bioengineers and their associated fauna respond differently to the effects of biogeography and upwelling. Ecology 91, 3549-3562.

Coley, P.D., Bryant, J.P. \& Chapin, F.S. 1985. Resource availability and plant antiherbivore defense. Science 230, 895-899.

Connell, J.H. 1978. Diversity in tropical rain forests and coral reefs. Science 199, 1302-1310.

Connolly, S.R. \& Roughgarden, J. 1999. Theory of marine communities: competition, predation, and recruitment-dependent interaction strength. Ecological Monographs 69, 277-296.

Courchamp, F., Clutton-Brock, T. \& Grenfell, B. 1999. Inverse density dependence and the Allee effect. Trends in Ecology \& Evolution 14, 405-410.

Crain, C.M. \& Bertness, M.D. 2006. Ecosystem engineering across environmental gradients: implications for conservation and management. BioScience 56, 211-218.

Cronon, W. 1983. Changes in the Land: Indians, Colonists and the Ecology of New England. New York: Hill and Wang.

Crooks, J.A. 2002. Characterizing ecosystem-level consequences of biological invasions: the role of ecosystem engineers. Oikos 97, 153-166.

Crutsinger, G.M., Souza, L. \& Sanders, N.J. 2008. Intraspecific diversity and dominant genotypes resist plant invasions. Ecology Letters 11, 16-23.

Dalby, J.E.J. 1996. Nemertean, copepod, and amphipod symbionts of the dimorphic ascidian Pyura stolonifera near Melbourne, Australia: specificities to host morphs, and factors affecting prevalences. Marine Biology 126, 231-243.

Dalby, J.E.J. 1997. Dimorphism in the ascidian Pyura stolonifera near Melbourne, Australia, and its evaluation through field transplant experiments. Marine Ecology 18, 253-271.

Day, R.W., Barkai. A. \& Wickens, P.A. 1991. Trapping of three drilling whelks by two species of mussel. Journal of Experimental Marine Biology and Ecology 149, 109-122

Dayton, P.K. 1971, Competition, disturbance, and community organization - provision and subsequent utilization of space in a rocky intertidal community. Ecological Monographs 41, 351-389.

Dayton, P.K. 1975. Experimental evaluation of ecological dominance in a rocky intertidal algal community. Ecological Monographs 45, 137-159.

Donahue, M.J. 2006. Allee effects and conspecific cueing jointly lead to conspecific attraction. Oecologia $149,33-43$.

Downing, J.A., Rochon, Y., Pérusse, M. \& Harvey, H. 1993. Spatial aggregation, body size, and reproductive success in the freshwater mussel Elliptio complanata. Journal of the North American Benthological Society 12, 148-156.

Eriksson, B.K., van der Heide, T., van de Koppel, J., Piersma, T., van der Veer, H.W. \& Olff, H. 2010. Major changes in the ecology of the Wadden Sea: human impacts, ecosystem engineering and sediment dynamics. Ecosystems 13, 752-764.

Erlandsson, J. \& McQuaid, C.D. 2004. Spatial structure of recruitment in the mussel Perna perna at local scales: effects of adults, algae and recruit size. Marine Ecology Progress Series 267, 173-185.

Erlandsson, J., Pal, P. \& McQuaid, C.D. 2006. Re-colonisation rate differs between co-existing indigenous and invasive intertidal mussels following major disturbance. Marine Ecology Progress Series 320, 169-176.

Fairweather, P.G. 1991. A conceptual framework for ecological studies of coastal resources: an example of a tunicate collected for bait on Australian Seashores. Ocean and Shoreline Management 15, 125-142.

Farrell, E.D. \& Crowe, T.P. 2007. The use of byssus threads by Mytilus edulis as an active defence against Nucella lapillus. Journal of the Marine Biological Association of the United Kingdom 87, 559-564. 
Fiala-Médioni, A. 1978. Filter-feeding ethology of benthic invertebrates (ascidians). IV. Pumping rate, filtration rate, filtration efficiency. Marine Biology 48, 243-249.

Fielding, P.J,, Weerts, K.A. \& Forbes, A.T. 1994. Macroinvertebrate communities associated with intertidal and subtidal beds of Pyura stolonifera (Heller) (Tunicata: Ascidiacea) on the Natal coast. South African Journal of Zoology 29, 46-53.

Fletcher, L. 2014. Background information on the sea squirt Pyura doppelgangera to support regional response decisions. Cawthron Institute, report prepared for Marlborough District Council, Nelson, New Zealand.

Flinn, M.V., Geary, D.C. \& Ward, C.V. 2005. Ecological dominance, social competition, and coalitionary arms races. Evolution and Human Behavior 26, 10-46.

Fox, J.W. 2013. The intermediate disturbance hypothesis should be abandoned. Trends in Ecology \& Evolution 28, 86-92.

Garrabou, J., Coma, R., Bensoussan, N., Bally, M., Chevaldonné, P., Cigliano, M., Diaz, D., Harmelin, J.G., Gambi, M.C., Kersting, D.K., Ledoux, J.B., Lejeusne, C., Linares, C., Marschal, C., Pérez, T., Ribes, M., Romano, J.C., Serrano, E., Teixido, N., Torrents, O., Zabala, M., Zuberer, F. \& Cerrano, C. 2009. Mass mortality in Northwestern Mediterranean rocky benthic communities: effects of the 2003 heat wave. Global Change Biology 15, 1090-1103.

Gascoigne, J. \& Lipcius, R.N. 2004. Allee effects in marine systems. Marine Ecology Progress Series 269, 49-59.

Gelcich, S., Cinner, J., Donlan, C.J., Tapia-Lewin, S., Godoy, N. \& Castilla, J.C. 2017. Fishers' perceptions on the Chilean coastal TURF system after two decades: problems, benefits, and emerging needs. Bulletin of Marine Science 93, 53-67.

Gili, J.-M. \& Coma, R. 1998. Benthic suspension feeders: their paramount role in littoral marine food webs. Trends in Ecology \& Evolution 13, 316-321.

Goss-Custard, J.D., West, A.D., Yates, M.G., Caldow, R.W., Stillman, R.A., Bardsley, L., Castilla, J., Castro, M., Dierschke, V., Durell, S.E., Eichhorn, G., Ens, B.J., Exo, K.M., Udayangani-Fernando, P.U., Ferns, P.N., Hockey, P.A., Gill, J.A., Johnstone, I., Kalejta-Summers, B., Masero, J.A., Moreira, F., Nagarajan, R.V., Owens, I.P., Pacheco, C., Perez-Hurtado, A., Rogers, D., Scheiffarth, G., Sitters, H., Sutherland, W.J., Triplet, P., Worrall, D.H., Zharikov, Y., Zwarts, L. \& Pettifor, R.A. 2006. Intake rates and the functional response in shorebirds (Charadriiformes) eating macro-invertebrates. Biological Reviews 81, 501-529.

Grosberg, R.K. \& Quinn, J.F. 1986. The genetic control and consequences of kin recognition by the larvae of a colonial marine invertebrate. Nature 322, 456-459.

Guiler, E.R. 1959. Intertidal belt-forming species on the rocky coasts of northern Chile. Papers and Proceedings of the Royal Society of Tasmania 93, 33-58.

Guiñez, R. \& Castilla, J.C. 1999. A tridimensional self-thinning model for multilayered intertidal mussels. American Naturalist 154, 341-357.

Guiñez, R. \& Castilla, J.C. 2001. An allometric tridimensional model of self-thinning for a gregarious tunicate. Ecology 82, 2331-2341.

Gutiérrez, J.L., Jones, C.G., Strayer, D.L. \& Iribarne, O.O. 2003. Mollusks as ecosystem engineers: the role of shell production in aquatic habitats. Oikos 101, 79-90.

Hanekom, N. 2013. Environmental conditions during mass mortalities of the ascidian Pyura stolonifera (Heller) in the Tsitsikamma Marine Protected Area. African Zoology 48, 167-172.

Hanekom, N., Harris, J.M., Branch, G.M. \& Allen, J.C. 1999. Mass mortality and recolonization of Pyura stolonifera (Heller) on the south coast of South Africa. South African Journal of Marine Science 21, 117-133.

Harley, C.D.G. 2006. Effects of physical ecosystem engineering and herbivory on intertidal community structure. Marine Ecology Progress Series 317, 29-39.

Hawkins, S.J. \& Hartnoll, R.G. 1983. Grazing of intertidal algae by marine invertebrates. Oceanography and Marine Biology: An Annual Review 21, 195-282.

Hayward, B.W. \& Morley, M.S. 2009. Introduction to New Zealand of two sea squirts (Tunicata, Ascidiacea) and their subsequent dispersal. Records of the Auckland Museum 46, 5-14.

Heasman, K.G., Pitcher, G.C., McQuaid, C.D. \& Hecht, T. 1998. Shellfish mariculture in the Benguela system: raft culture of Mytilus galloprovincialis and the effect of rope spacing on food extraction, growth rate, production, and condition of mussels. Journal of Shellfish Research 17, 33-39.

Heller, C. 1878. Beiträge zur näheren Kenntniss der Tunicaten. Sitzungsberichte der Academie der Wissenschaften in Wien 77, 83-109. 
Hillebrand, H., Bennett, D.M. \& Cadotte, M.W. 2008. Consequences of dominance: a review of evenness effects on local and regional ecosystem processes. Ecology 89, 1510-1520.

Hughes, R.N. \& Griffiths, C.L. 1988. Self-thinning in barnacles and mussels: the geometry of packing. American Naturalist 132, 484-491.

Johnson, C.H. \& Woollacott, R.M. 2010. Larval settlement preference maximizes genetic mixing in an inbreeding population of a simultaneous hermaphrodite (Bugula stolonifera, Bryozoa). Molecular Ecology 19, 5511-5520.

Jones, C.G., Lawton, J.H. \& Shachak, M. 1994. Organisms as ecosystem engineers. Oikos 69, 373-386.

Jones, C.G., Lawton, J.H. \& Shachak, M. 1997. Positive and negative effects of organisms as physical ecosystem engineers. Ecology 78, 1946-1957.

Jordan, W.R. 2000. Restoration, community, and wilderness. In Restoring Nature. Perspectives from the Social Sciences and Humanities, P.H. Gobster \& R.B. Hull (eds). Washington, DC: Island Press, 21-36.

Justus, J., Colyvan, M., Regan, H. \& Maguire, L. 2009. Buying into conservation: intrinsic versus instrumental value. Trends in Ecology \& Evolution 24, 187-191.

Katz, E. 1992. The big lie: human reconstuction of nature. Research in Philosophy and Technology 12, 231-241.

Katz, E. 2000. Another look at restoration: technology and artificial nature. In Restoring Nature. Perspectives from the Social Sciences and Humanities, P.H. Gobster \& R.B. Hull (eds). Washington, DC: Island Press, 37-48.

Keller, L.F. \& Waller, D.M. 2002. Inbreeding effects in wild populations Trends in Ecology \& Evolution 17, 230-241.

Keough, M.J., Quinn, G.P. \& King, A. 1993. Correlations between human collecting and intertidal mollusc populations on rocky shores. Conservation Biology 7, 378-390.

Keough, M.J. \& Raimondi, P.T. 1995. Responses of settling invertebrate larvae to bioorganic films: effects of different types of films. Journal of Experimental Marine Biology and Ecology 185, 235-253.

Kingsford, M.J., Underwood, A.J. \& Kennelly, S.J. 1991. Humans as predators on rocky reefs in New South Wales, Australia. Marine Ecology Progress Series 72, 1-14.

Kinlan, B.P. \& Gaines, S. 2003. Dispersal in marine and terrestrial environments: a community perspective. Ecology 84, 2007-2020.

Kinlan, B.P., Gaines, S.D. \& Lester, S.E. 2005. Propagule dispersal and the scales of marine community process. Diversity and Distributions 11, 139-148.

Klumpp, D.W. 1984. Nutritional ecology of the ascidian Pyura stolonifera: influence of body size, food quantity and quality on filter-feeding, respiration, assimilation efficiency and energy balance. Marine Ecology Progress Series 19, 269-284.

Knott, N.A., Davis, A.R. \& Buttemer, W.A. 2004. Passive flow through an unstalked intertidal ascidian: orientation and morphology enhance suspension feeding in Pyura stolonifera. Biological Bulletin 207, 217-224.

Kott, P. 1952. The ascidians of Australia I. Stolidobranchiata lahille and Phlebobranchiata lahille. Australian Journal of Marine and Freshwater Research 3, 205-333.

Kott, P. 1985. The Australian Ascidiacea, Part 1. Phlebobranchia and Stolidobranchia. Memoirs of the Queensland Museum 23, 1-440.

Kott, P. 2006. Observations on non-didemnid ascidians from Australian waters. Journal of Natural History 40, 169-234.

Kuussaari, M., Saccheri, I., Camara, M. \& Hanski, I. 1998. Allee effect and population dynamics in the Glanville fritillary butterfly. Oikos 82, 384-392.

Kyle, R., Pearson, B., Fielding, P.J., Robertson, W.D. \& Birnie, S.L. 1997. Subsistence shellfish harvesting in the Maputaland marine reserve in northern Kwazulu-Natal, South Africa: rocky shore organisms. Biological Conservation 82, 183-192.

Lafargue, F. \& Wahl, M. (1986-1987) Contribution to the knowledge of littoral ascidians (Ascidiacea, Tunicata) of the Senegalese coast. Bulletin de l'IFAN 46, 385-402.

Lambert, G. 2005. Ecology and natural history of the protochordates. Canadian Journal of Zoology 83, $34-50$.

Lambert, G. (2007) Invasive sea squirts: a growing global problem. Journal of Experimental Marine Biology and Ecology 342, 3-4. 
Lasiak, T. 1991. The susceptibility and/or resilience of rocky littoral molluscs to stock depletion by the indigenous coastal people of Transkei, Southern Africa. Biological Conservation 56, 245-264.

Lawton, J.H. \& Jones, C.G. 1995. Linking species and ecosystems: organisms as ecosystem engineers. In Linking Species and Ecosystems, C.G. Jones \& J.H. Lawton (eds). Springer, 141-150.

LeBlanc, N., Davidson, J., Tremblay, R., McNiven, M. \& Landry, T. 2007. The effect of anti-fouling treatments for the clubbed tunicate on the blue mussel, Mytilus edulis. Aquaculture 264, 205-213.

Lehane, C. \& Davenport, J. 2004. Ingestion of bivalve larvae by Mytilus edulis: experimental and field demonstrations of larviphagy in farmed blue mussels. Marine Biology 145, 101-107.

Leibold, M.A., Holyoak, M., Mouquet, N., Amarasekare, P., Chase, J.M., Hoope, M.F., Holt, R.D., Shurin, J.B., Law, R., Tilman, D., Loreau, M. \& Gonzalez, A. 2004. The metacommunity concept: a framework for multi-scale community ecology. Ecology Letters 7, 601-613.

Levins, R. 1974. The qualitative analysis of partially specified systems. Annals of the New York Academy of Sciences 231, 123-138.

Levitan, D.R. 1991. Influence of body size and population density on fertilization success and reproductive output in a free-spawning invertebrate. Biological Bulletin 181, 261-268.

Levitan, D.R., Sewell, M.A. \& Chia, F.-S. 1992. How distribution and abundance influence fertilization success in the sea urchin Strongylocentotus franciscanus. Ecology 73, 248-254.

Locke, A. 2009. A screening procedure for potential tunicate invaders of Atlantic Canada. Aquatic Invasions 4, 71-79.

Loo, L.-O. \& Rosenberg, R. 1989. Bivalve suspension-feeding dynamics and benthic-pelagic coupling in an eutrophicated marine bay. Journal of Experimental Marine Biology and Ecology 130, 253-276.

Loo, L.-O. \& Rosenberg, R. 1996. Production and energy budget in marine suspension feeding populations: Mytilus edulis, Cerastoderma edule, Mya arenaria and Amphiura filiformis. Journal of Sea Research 35, 199-207.

Loreau, M., Naeem, S., Inchausti, P., Bengtsson, J., Grime, J.P., Hector, A., Hooper, D.U., Huston, M.A., Raffaelli, D., Schmid, B., Tilman, D. \& Wardle, D.A. 2001. Biodiversity and ecosystem functioning: current knowledge and future challenges. Science 294, 804-808.

Lubchenco, J. 1978. Plant species diversity in a marine intertidal community: importance of herbivore food preference and algal competitive abilities. American Naturalist 112, 23-39.

Lubchenco, J. \& Gaines, S.D. 1981. A unified approach to marine plant-herbivore interactions. I. Populations and communities. Annual Review of Ecology and Systematics 12, 405-437.

Lubchenco, J. \& Menge, B.A. 1978. Community development and persistence in a low rocky intertidal zone. Ecological Monographs 48, 67-94.

Majiza, V.N. \& Lasiak, T.A. 2010. The influence of site, season and day of the week on exploitation of rocky intertidal biota in central Transkei, South Africa. South African Journal of Marine Science 24, 57-64.

Manríquez, P.H. \& Castilla, J.C. 2010. Fertilization efficiency and gamete viability in the ascidian Pyura praeputialis in Chile. Marine Ecology Progress Series 409, 107-119.

Manríquez, P.H., Castilla, J.C., Ortiz, V. \& Jara, M.E. 2016. Empirical evidence for large-scale human impact on intertidal aggregations, larval supply and recruitment of Pyura praeputialis around the Bay of Antofagasta, Chile. Austral Ecology 41, 701-714.

Manríquez, P.H., Delgado, A.P., Jara, M.E. \& Castilla, J.C. 2008. Field and laboratory pilot rearing experiments with early ontogenic stages of Concholepas concholepas (Gastropoda: Muricidae). Aquaculture 279, 99-107.

Manríquez, P.H., Jara, M.E., Mardones, M.L., Torres, R., Lagos, N.A., Lardies, M.A., Vargas, C.A., Duarte, C. \& Navarro, J.M. 2014. Effects of ocean acidification on larval development and early post-hatching traits in Concholepas concholepas (loco). Marine Ecology Progress Series 514, 87-103.

Marshall, D.J. 2002. In situ measures of spawning synchrony and fertilization success in an intertidal, freespawning invertebrate. Marine Ecology Progress Series 236, 113-119.

Marshall, D.J. \& Keough, M.J. 2008. The evolutionary ecology of offspring size in marine invertebrates. Advances in Marine Biology 53, 1-60.

Marshall, D.J., Krug, P.J., Kupriyanova, E.K., Byrne, M. \& Emlet, R.B. 2012. The biogeography of marine invertebrate life histories. Annual Review of Ecology, Evolution, and Systematics 43, 97-114.

Marshall, D.J., Styan, C.A. \& Keough, M.J. 2000. Intraspecific co-variation between egg and body size affects fertilisation kinetics of free-spawning marine invertebrates. Marine Ecology Progress Series 195, 305-309. 
McQuaid, C.D. \& Branch, G.M. 1984. The influence of sea temperature, substratum and wave exposure on rocky intertidal communities: an analysis of faunal and floral biomass. Marine Ecology Progress Series 19, 145-151.

McQuaid, C.D. \& Branch, G.M. 1985. Trophic structure of rocky intertidal communities: response to wave action and implications for energy flow. Marine Ecology Progress Series 22, 153-161.

McQuaid, C.D. \& Lindsay, J.R. 2005. Interacting effects of wave exposure, tidal height and substratum on spatial variation in densities of mussel Perna perna plantigrades. Marine Ecology Progress Series 301, 173-184.

McQuaid, C.D. \& Phillips, T.E. 2000. Limited wind-driven dispersal of intertidal mussel larvae: in situ evidence from the plankton and the spread of the invasive species Mytilus galloprovincialis in South Africa. Marine Ecology Progress Series 201, 211-220.

Menge, B.A., Berlow, E.L., Blanchette, C.A., Navarrete, S.A. \& Yamada, S.B. 1994. The keystone species concept - variation in interaction strength in a rocky intertidal habitat. Ecological Monographs 64, $249-286$.

Menge, B.A. \& Sutherland, J.P. 1987. Community regulation - variation in disturbance, competition, and predation in relation to environmental-stress and recruitment. American Naturalist 130, 730-757.

Millar, R.H. 1955. On a collection of ascidians from South Africa. Proceedings of the Zoological Society of London 125, 169-221.

Millar, R.H. 1962. Further descriptions of South African ascidians. Annals of the South African Museum 46, $113-221$.

Millar, R.H. 1966. Port Phillip survey 1957-1963. Ascidiacea. Memoirs of the National Museum of Victoria 27, 357-384.

Millar, R.H. 1971. The biology of ascidians. Advances in Marine Biology 9, 1-100.

Monniot, C. \& Bitar, G. 1983. Sur la présence de Pyura stolonifera (Tunicata, Ascidiacea) à Ras Achaccar (côte nord atlantique marocaine). Comparaison anatomique distinctive avec Pyura praeputialis. Bulletin de l'Institut Scientifique, Rabat 7, 83-91.

Monniot, C., Monniot, F., Griffiths, C.L. \& Schleyer, M. 2001. South African ascidians. Annals of the South African Museum 108, 1-141.

Monniot, C., Monniot, F. \& Laboute, P. 1991. Coral Reef Ascidians of New Caledonia. Paris: Éditions de L'Orstom.

Monniot, F. \& Monniot, C. 2001. Ascidians from the tropical western Pacific. Zoosystema 23, 201-383.

Monteiro, S.M., Chapman, M.G. \& Underwood, A.J. 2002. Patches of the ascidian Pyura stolonifera (Heller, 1878): structure of habitat and associated intertidal assemblages. Journal of Experimental Marine Biology and Ecology 270, 171-189.

Moreno, C.A., Sutherland, J.P. \& Jara, H.F. 1984. Man as a predator in the intertidal zone of southern Chile. Oikos 42, 155-160.

Navarrete, S.A. \& Berlow, E.L. 2006. Variable interaction strengths stabilize marine community pattern. Ecology Letters 9, 526-536.

Navarrete, S.A. \& Castilla, J.C. 2003. Experimental determination of predation intensity in an intertidal predator guild: dominant versus subordinate prey. Oikos 100, 251-262.

Navarrete, S.A., Wieters, E.A., Broitman, B.R. \& Castilla, J.C. 2005. Scales of benthic-pelagic coupling and the intensity of species interactions: from recruitment limitation to top-down control. Proceedings of the National Academy of Sciences of the USA 102, 18046-18051.

Newell, R.C., Field, J.G. \& Griffiths, C.L. 1982. Energy balance and significance of microorganisms in a kelp bed community. Marine Ecology Progress Series 8, 103-113.

Nilsson, M.-C. \& Wardle, D.A. 2005. Understory vegetation as a forest ecosystem driver: evidence from the northern Swedish boreal forest. Frontiers in Ecology and the Environment 3, 421-428.

Oldewage, W.H. 1994. Description of Doropygus pyurus n.sp. (Copepoda, Notodelphyidae) from Pyura stolonifera (Echinodermata, Ascidiacea) in South Africa. South African Journal of Zoology 29, 212-216.

Ortiz, M., Campos, L., Berrios, F., Rodriguez, F., Hermosillo, B. \& González, J. 2013. Network properties and keystoneness assessment in different intertidal communities dominated by two ecosystem engineer species (SE Pacific coast): a comparative analysis. Ecological Modelling 250, 307-318.

Otway, N.M. 1989. The effects of grazing by chitons on mid and low shore intertidal communities. PhD thesis, University of Sydney, Australia. 
Pacheco, C.J. \& Castilla, J.C. 2001. Foraging behavior of the American oystercatcher Haematopus palliatus pitanay (Murphy 1925) on the intertidal ascidian Pyura praeputialis (Heller 1878) in the Bay of Antofagasta, Chile. Journal of Ethology 19, 23-26.

Paine, R.T. 1966. Food web complexity and species diversity. American Naturalist 100, 65-75.

Paine, R.T. 1969. A note on trophic complexity and community stability. American Naturalist 103, 91-93.

Paine, R.T. 1971. Short-term experimental investigation of resource partitioning in a New Zealand rocky intertidal habitat. Ecology 52, 1096-1106.

Paine, R.T. 1976. Size-limited predation: an observational and experimental approach with the MytilusPisaster interaction. Ecology 57, 858-873.

Paine, R.T. 1979. Disaster, catastrophe, and local persistence of the sea palm Postelsia palmaeformis. Science 205, 685-687.

Paine, R.T., Castilla, J.C. \& Cancino, J. 1985. Perturbation and recovery patterns of starfish-dominated intertidal assemblages in Chile, New Zealand, and Washington State. American Naturalist 125, 679-691.

Paine, R.T. \& Suchanek, T.H. 1983. Convergence of ecological processes between independently evolved competitive dominants: a tunicate-mussel comparison. Evolution 37, 821-831.

Pawlik, J.R., Butman, C.A. \& Starczak, V.R. 1991. Hydrodynamic facilitation of gregarious settlement of a reef-building tube worm. Science 251, 421-423.

Petersen, J.K. \& Riisgård, H.U. 1992. Filtration capacity of the ascidian Ciona intestinalis and its grazing impact in a shallow fjord. Marine Ecology Progress Series 88, 9-17.

Petersen, J.K. \& Svane, I. 2002. Filtration rate in seven Scandinavian ascidians: implications of the morphology of the gill sac. Marine Biology 140, 397-402.

Porri, F., Jordaan, T. \& McQuaid, C.D. 2008. Does cannibalism of larvae by adults affect settlement and connectivity of mussel populations? Estuarine, Coastal and Shelf Science 79, 687-693.

Quoy, J. \& Gaimard, A. 1834. Animaux Mollusques. In Voyages de Decouvertes de l'Astrolabe Executes par Orde du Roi, Pendant les Annees 1826-29, sous le Commandement de M.J. Dumont d'Urville, Zoologie, Vol 3, 559-625.

Ramírez, M.E. \& Mena, O. 1984. Distribucion, abundancia y estructuras de las comunidades de algas que crecen sobre Pyura praeputialis Heller, 1878 en Caleta Coloso (Antofagasta). Boletin Museo Nacional Historia Nacional Chile 40, 7-21.

Ramorino, L. \& Campos, B. 1983. Larvas y postlarvas de Mytilidae de Chile (Mollusca: Bivalvia). Revista de Biología Marina 19, 143-192.

Randløv, A. \& Riisgård, H.U. 1979. Efficiency of particle retention and filtration rate in four species of ascidians. Marine Ecology Progress Series 1, 55-59.

Reed, J.M. \& Dobson, A.P. 1993. Behavioural constraints and conservation biology: conspecific attraction and recruitment. Trends in Ecology \& Evolution 8, 253-256.

Ribes, M., Coma, R. \& Gili, J.M. 1998. Seasonal variation of in situ feeding rates by the temperate ascidian Halocynthia papillosa. Marine Ecology Progress Series 175, 201-213.

Richardson, D.M., Pyšek, P., Rejmánek, M., Barbour, M.G., Panetta, F.D. \& West, C.J. 2000. Naturalization and invasion of alien plants: concepts and definitions. Diversity and Distributions 6, 93-107.

Rius, M., Branch, G.M., Griffiths, C.L. \& Turon, X. 2010a. Larval settlement behaviour in six gregarious ascidians in relation to adult distribution. Marine Ecology Progress Series 418, 151-163.

Rius, M. \& Cabral, H.N. 2004. Human harvesting of Mytilus galloprovincialis Lamarck, 1819, in the central coast of Portugal. Scientia Marina 68, 545-551.

Rius, M., Clusella-Trullas, S., McQuaid, C.D., Navarro, R.A., Griffiths, C.L., Matthee, C.A., von der Heyden, S. \& Turon, X. 2014a. Range expansions across ecoregions: interactions of climate change, physiology and genetic diversity. Global Ecology and Biogeography 23, 76-88.

Rius, M. \& Darling, J.A. 2014. How important is intraspecific genetic admixture to the success of colonising populations? Trends in Ecology \& Evolution 29, 233-242.

Rius, M., Kaehler, S. \& McQuaid, C.D. 2006. The relationship between human exploitation pressure and condition of mussel populations along the south coast of South Africa. South African Journal of Science 102, 130-136.

Rius, M. \& McQuaid, C.D. 2006. Wave action and competitive interaction between the invasive mussel Mytilus galloprovincialis and the indigenous Perna perna in South Africa. Marine Biology 150, 69-78.

Rius, M. \& McQuaid, C.D. 2009. Facilitation and competition between invasive and indigenous mussels over a gradient of physical stress. Basic and Applied Ecology 10, 607-613. 
Rius, M., Potter, E.E., Aguirre, J.D. \& Stachowicz, J.J. 2014b. Mechanisms of biotic resistance across complex life cycles. Journal of Animal Ecology 83, 296-305.

Rius, M. \& Teske, P.R. 2011. A revision of the Pyura stolonifera species complex (Tunicata, Ascidiacea), with a description of a new species from Australia. Zootaxa 2754, 27-40.

Rius, M. \& Teske, P.R. 2013. Cryptic diversity in coastal Australasia: a morphological and mitonuclear genetic analysis of habitat-forming sibling species. Zoological Journal of the Linnean Society 168, 597-611.

Rius, M., Turon, X., Dias, G.M. \& Marshall, D.J. 2010b. Propagule size effects across multiple life-history stages in a marine invertebrate. Functional Ecology 24, 685-693.

Rius, M., Turon, X., Ordóñez, V. \& Pascual, M. 2012. Tracking invasion histories in the sea: facing complex scenarios using multilocus data. PLOS ONE 7, e35815.

Robinson, T.B., Griffiths, C.L., McQuaid, C.D. \& Rius, M. 2005. Marine alien species of South Africa - status and impacts. African Journal of Marine Science 27, 297-306.

Roy, K., Collins, A.G., Becker, B.J., Begovic, E. \& Engle, J.M. 2003. Anthropogenic impacts and historical decline in body size of rocky intertidal gastropods in southern California. Ecology Letters 6, 205-211.

Sale, P.F. 1977. Maintenance of high diversity in coral reef fish communities. American Naturalist 111, 337-359.

Sale, P.F. 1979. Recruitment, loss and coexistence in a guild of territorial coral reef fishes. Oecologia 42, 159-177.

Sarà, M 1986. Sessile macrofauna and marine ecosystem. Bolletino di Zoologia 53, 329-337.

Schoener, T.W. 1983. Field experiments on interspecific competition. American Naturalist 122, 240-285.

Schultz, M. 1989. Sooty oystercatcher feeding on washed-up cunjevoi. Stilt 14, 66-67.

Seiderer, L.J. \& Newell, R.C. 1988. Exploitation of phytoplankton as a food resource by the kelp bed ascidian Pyura stolonifera. Marine Ecology Progress Series 50, 107-115.

Sherrard, K.M. \& LaBarbera, M. 2005. Form and function in juvenile ascidians II. Ontogenetic scaling of volumetric flow rates. Marine Ecology Progress Series 287, 139-148.

Simberloff, D. 2010. Invasive species. In Conservation Biology for All, N.S. Sodhi \& P.R. Ehrlich (eds). Oxford: Oxford University Press, 131-152.

Simberloff, D. 2012. Nature, natives, nativism, and management: Worldviews underlying controversies in invasion biology. Environmental Ethics 34, 5-25.

Simberloff, D. \& Vitule, J.R.S. 2014. A call for an end to calls for the end of invasion biology. Oikos 123, 408-413.

Smith, J.R. \& Murray, S.N. 2005. The effects of experimental bait collection and trampling on a Mytilus californianus mussel bed in southern California. Marine Biology 147, 699-706.

Smith, M.D. \& Knapp, A.K. 2003. Dominant species maintain ecosystem function with non-random species loss. Ecology Letters 6, 509-517.

Soulé, M. 1995. The social siege of nature. In Reinventing Nature? Responses to Postmodern Deconstruction. M. Soulé \& G. Lease (eds). Washington DC, Island Press, 137-170.

Sousa, W.P. 1979. Experimental investigations of disturbance and ecological succession in a rocky intertidal algal community. Ecological Monographs 49, 227-254.

Stachowicz, J.J. \& Hay, M.E. 1999. Reducing predation through chemically mediated camouflage: indirect effects of plant defenses on herbivores. Ecology 80, 495-509.

Steinwascher, K. 1978. Interference and exploitation competition among tadpoles of Rana utricularia. Ecology 59, 1039-1046.

Steneck, R.S., Hacker, S.D. \& Dethier, M.N. 1991. Mechanisms of competitive dominance between crustose coralline algae: an herbivore-mediated competitive reversal. Ecology 72, 938-950.

Stephens, P.A. \& Sutherland, W.J. 1999. Consequences of the Allee effect for behaviour, ecology and conservation. Trends in Ecology \& Evolution 14, 401-405.

Stephenson, T.A. \& Stephenson, A. 1972. Life Between Tidemarks on Rocky Shores. San Francisco: W.H. Freeman and Company.

Stuart, V. \& Klumpp, D.W. 1984. Evidence for food-resource partitioning by kelp-bed filter feeders. Marine Ecology Progress Series 16, 27-37.

Symondson, W.O.C., Sunderland, K.D. \& Greenstone, M.H. 2002. Can generalist predators be effective biocontrol agents? Annual Review of Entomology 47, 561-594.

Tapia, F.J. \& Pineda, J. 2007. Stage-specific distribution of barnacle larvae in nearshore waters: potential for limited dispersal and high mortality rates. Marine Ecology Progress Series 342, 177-190. 
Teske, P.R. 2014. Connectivity in solitary ascidians: is a 24-h propagule duration sufficient to maintain largescale genetic homogeneity? Marine Biology 161, 2681-2687.

Teske, P.R., Rius, M., McQuaid, C.D., Styan, C.A., Piggott, M.P., Benhissoune, S., Fuentes-Grünewald, C., Walls, K., Page, M., Attard, C.R.M., Cooke, G.M., McClusky, C.F., Banks, S.C., Barker, N.P. \& Beheregaray, L.B. 2011. "Nested" cryptic diversity in a widespread marine ecosystem engineer: a challenge for detecting biological invasions. BMC Evolutionary Biology 11, 176.

Teske, P.R., Sandoval-Castillo, J., Sasaki, M. \& Beheregaray, L.B. 2015. Invasion success of a habitat-forming marine invertebrate is limited by lower-than-expected dispersal ability. Marine Ecology Progress Series 536, 221-227.

Teske, P.R., Sandoval-Castillo, J., van Sebille, E., Waters, J. \& Beheregaray, L.B. 2016. Oceanography promotes self-recruitment in a planktonic larval disperser. Scientific Reports 6, 34205.

Teske, P.R., Sandoval-Castillo, J., Waters, J.M. \& Beheregaray, L.B. 2014. Can novel genetic analyses help to identify low-dispersal marine invasive species? Ecology and Evolution 4, 2848-2866.

Thorson, G. 1950. Reproductive and larval ecology of marine bottom invertebrates. Biological Reviews 25, $1-45$.

Tilman, D. 1994. Competition and biodiversity in spatially structured habitats. Ecology 75, 2-16.

Toonen, R.J. \& Pawlik, J.R. 1994. Foundations of gregariousness. Nature 370, 511-512.

Toonen, R.J. \& Pawlik, J.R. 1996. Settlement of the tube worm Hydroides dianthus (Polychaeta: Serpulidae): cues for gregarious settlement. Marine Biology 126, 725-733.

Troost, K., Kamermans, P. \& Wolff, W.J. 2008. Larviphagy in native bivalves and an introduced oyster. Journal of Sea Research 60, 157-163.

Tsuchiya, M. 1983. Mass mortality in a population of the mussel Mytilus edulis L. caused by high temperature on rocky shores. Journal of Experimental Marine Biology and Ecology 66, 101-111.

Tyree, S. 2001. The Ascidians (Sea Squirts). Their Biology, Physiology and Natural Filtration Integration. Rancho Cucamonga: DE Publishing.

Underwood, A.J. 2000. Experimental ecology of rocky intertidal habitats: what are we learning? Journal of Experimental Marine Biology and Ecology 250, 51-76.

Underwood, A.J., Kingsford, M.J. \& Andrew, N.L. 1991. Patterns in shallow subtidal marine assemblages along the coast of New South Wales. Australian Journal of Ecology 16, 231-249.

United Nations 1997. Glossary of Environment Statistics. New York.

Vallejo-Marín, M. \& Hiscock, S.J. 2016. Hybridization and hybrid speciation under global change. New Phytologist 211, 1170-1187.

van de Koppel, J., Rietkerk, M., Dankers, N. \& Herman, P.M.J. 2005. Scale-dependent feedback and regular spatial patterns in young mussel beds. American Naturalist 165, E66-E77.

Van Driel, C.D. \& Steyl, C.D. 1978. A quantitative similarity analysis of fauna associated with growth forms of red bait (Pyura stolonifera) in Algoa Bay. In Proceedings of the First Interdisciplinary Conference on Marine and Freshwater Research in Southern Africa, 5-10 July 1976, University of Port Elizabeth, Summerstrand Campus, Port Elizabeth, South Africa. South African National Committee for Oceanographic Research.

Van Name, W.G. 1945. The North and South American ascidians. Bulletin of the American Museum of Natural History 84, 1-476.

Varner, G. 1990. Biological functions and biological interests. Southern Journal of Philosophy 17, 251-270.

Varner, G. 1998. In Nature's Interest? Interest, Animal Rights and Environmental Ethics. Oxford: Oxford Univeristy Press.

Veliz, D., Duchesne, P., Bourget, E. \& Bernatchez, L. 2006. Genetic evidence for kin aggregation in the intertidal acorn barnacle (Semibalanus balanoides). Molecular Ecology 15, 4193-4202.

Vieira, E.A., Duarte, L.F.L. \& Dias, G.M. 2012. How the timing of predation affects composition and diversity of species in a marine sessile community? Journal of Experimental Marine Biology and Ecology 412, $126-133$.

von der Meden, C.E.O., Porri, F., McQuaid, C.D., Faulkner, K. \& Robey, J. 2010. Fine-scale ontogenetic shifts in settlement behaviour of mussels: changing responses to biofilm and conspecific settler presence in Mytilus galloprovincialis and Perna perna. Marine Ecology Progress Series 411, 161-171.

Wieczorek, S.K. \& Todd, C.D. 1997. Inhibition and facilitation of bryozoan and ascidian settlement by natural multi-species biofilms: effects of film age and the roles of active and passive larval attachment. Marine Biology 128, 463-473. 


\section{MARC RIUS ET AL.}

Wright, A., Pérez-Portela, R. \& Griffiths, C.L. 2016. Determining the correct identity of South African Marthasterias (Echinodermata: Asteroidea). African Journal of Marine Science 38, 443-455.

Wright, J.P. \& Jones, C.G. 2006. The concept of organisms as ecosystem engineers ten years on: Progress, limitations, and challenges. BioScience 56, 203-209.

Yodzis, P. 1989. Introduction to Theoretical Ecology. New York: Harper and Row.

Young, C.M. 1988. Ascidian cannibalism correlates with larval behavior and adult distribution. Journal of Experimental Marine Biology and Ecology 117, 9-26. 
